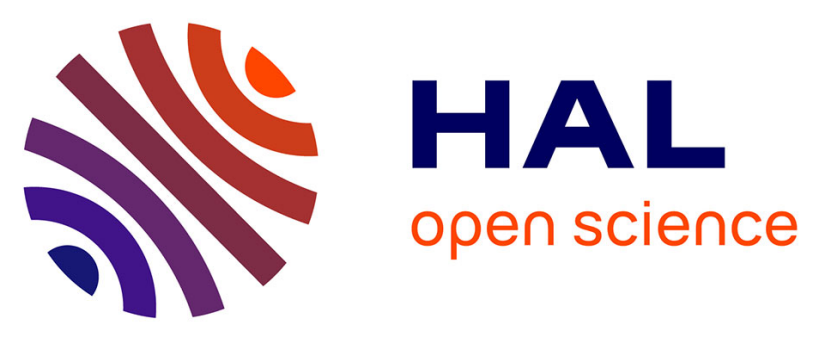

\title{
3D geological modelling at urban scale and mapping of ground movement susceptibility from gypsum dissolution: The Paris example (France)
}

Pierre Thierry, Anne-Marie Prunier-Leparmentier, Carole Lembezat, Emilie Vanoudheusden, Jean-François Vernoux

\section{To cite this version:}

Pierre Thierry, Anne-Marie Prunier-Leparmentier, Carole Lembezat, Emilie Vanoudheusden, JeanFrançois Vernoux. 3D geological modelling at urban scale and mapping of ground movement susceptibility from gypsum dissolution: The Paris example (France). Engineering Geology, 2009, 105 (1-2), p. 51-64. 10.1016/j.enggeo.2008.12.010 . hal-00514427

\section{HAL Id: hal-00514427 https: / hal-brgm.archives-ouvertes.fr/hal-00514427}

Submitted on 7 Oct 2010

HAL is a multi-disciplinary open access archive for the deposit and dissemination of scientific research documents, whether they are published or not. The documents may come from teaching and research institutions in France or abroad, or from public or private research centers.
L'archive ouverte pluridisciplinaire HAL, est destinée au dépôt et à la diffusion de documents scientifiques de niveau recherche, publiés ou non, émanant des établissements d'enseignement et de recherche français ou étrangers, des laboratoires publics ou privés. 


\title{
3D geological modelling at urban scale and mapping of ground movement susceptibility from gypsum dissolution: the Paris example (France)
}

\section{Pierre THIERRY ${ }^{1}$, Anne-Marie PRUNIER-LEPARMENTIER ${ }^{2}$, Carole LEMBEZAT ${ }^{1}$, Emilie VANOUDHEUSDEN ${ }^{1}$, Jean-François VERNOUX ${ }^{3}$}

\author{
1: BRGM ARN BP36009 45060 Orléans CEDEX 2, France \\ 2: IGC 3, avenue du Colonel Henri Rol-Tanguy 75014 Paris, France \\ 3: BRGM EAU BP36009 45060 Orléans CEDEX 2, France
}

\section{Abstract}

Gypsum dissolution can be the cause of damage associated with subsidence and collapse. In Paris, the authorities want to refine the current maps of the areas likely to be affected by ground movement due to gypsum dissolution in the Bartonian Saint Ouen Limestone and Beauchamp Sands, and in the Lutetian marl and limestone formation. The proposed method involves assessing separately the probabilities relative to factors that control the ground subsidence, i.e.: thickness of gypsum strata, sulphate-unsaturated water flows, groundwater level, thickness and nature of the overburden. The total susceptibility is represented in a map form by the product of these three values plotted on a grid map with a pixel size of $20 \mathrm{~m}$. For this, we developed a multi-layer 3D geological model using the same $20 \mathrm{~m}$ mesh grid, integrating 21 lithostratigraphic units. The hazard prone areas were calculated by geostatistical methods from the archived descriptions of more than 3900 boreholes and from existing geological maps. At the same time, the analysis of some 300 piezometers made it possible to construct the High Water (HW) and Low Water (LW) levels of the groundwater likely to have an impact on the dissolution of the gypsum. The obtained results correlate satisfactorily with the Parisian authorities' field knowledge and to the location of the known events. The mapping also revealed some sensitive areas that had not been previously identified; these will be checked by drilling. The constructed geological model and the 
hydrogeological analysis have already been used for studying other phenomena (e.g. sand flow and clay creep).

\section{Key words}

Paris, gypsum, collapse, 3D geological model, dissolution, groundwater

\section{Introduction}

Gypsum, hydrated calcium sulphate $\mathrm{CaSO}_{4}, 2\left(\mathrm{H}_{2} \mathrm{O}\right)$, is one of the most soluble minerals. Where it forms thick beds, it is likely to develop large dissolution cavities comparable to the karst features classically associated with calcareous or dolomitic rocks. These cavities can give rise to catastrophic collapse, especially in view of the mineral's rapid dissolution. Even without such catastrophic events, gypsum dissolution can cause problems at any construction site, e.g. foundations, excavations or underground structures (Jardin, 1975; Cooper and Saunders, 2002).

This problem is a major issue in many countries, including the United States (Johnson 2005), Turkey (Yilmaz, 2007), the United Kingdom (Cooper, 1995; Lamont-Black et al., 1999), Spain (Gutierrez and Cooper, 2002; Gutierrez-Santolalla et al., 2005) and China (Lu et al., 2002).

In France, the city of Paris and its suburbs are affected by this type of phenomenon (Soyer, 1961; Arnould, 1970; Toulemont, 1986). Thick beds of Ludian gypsum have been intensively worked for plaster, and a specific department, the Inspection Générale des Carrières (IGC; General Inspectorate of Quarries) has the task of managing the risks associated with these old workings. However, other gypsiferous formations that have not been excavated are also likely to be the cause of ground movements. The main subsidence problems are primarily associated with the so-called pre-Ludian formations which, below Paris, are the Bartonian (Late Eocene) Calcaires de Saint Ouen [Saint Ouen Limestone] and Sables de l'Auversien [Auversian Sands] (Sables de Beauchamp [Beauchamp Sands]) and the Lutetian (Middle 
Eocene) so-called "Marnes et Caillasses" ["Brackish Marl and Limestone"] formation (see Figure 1).

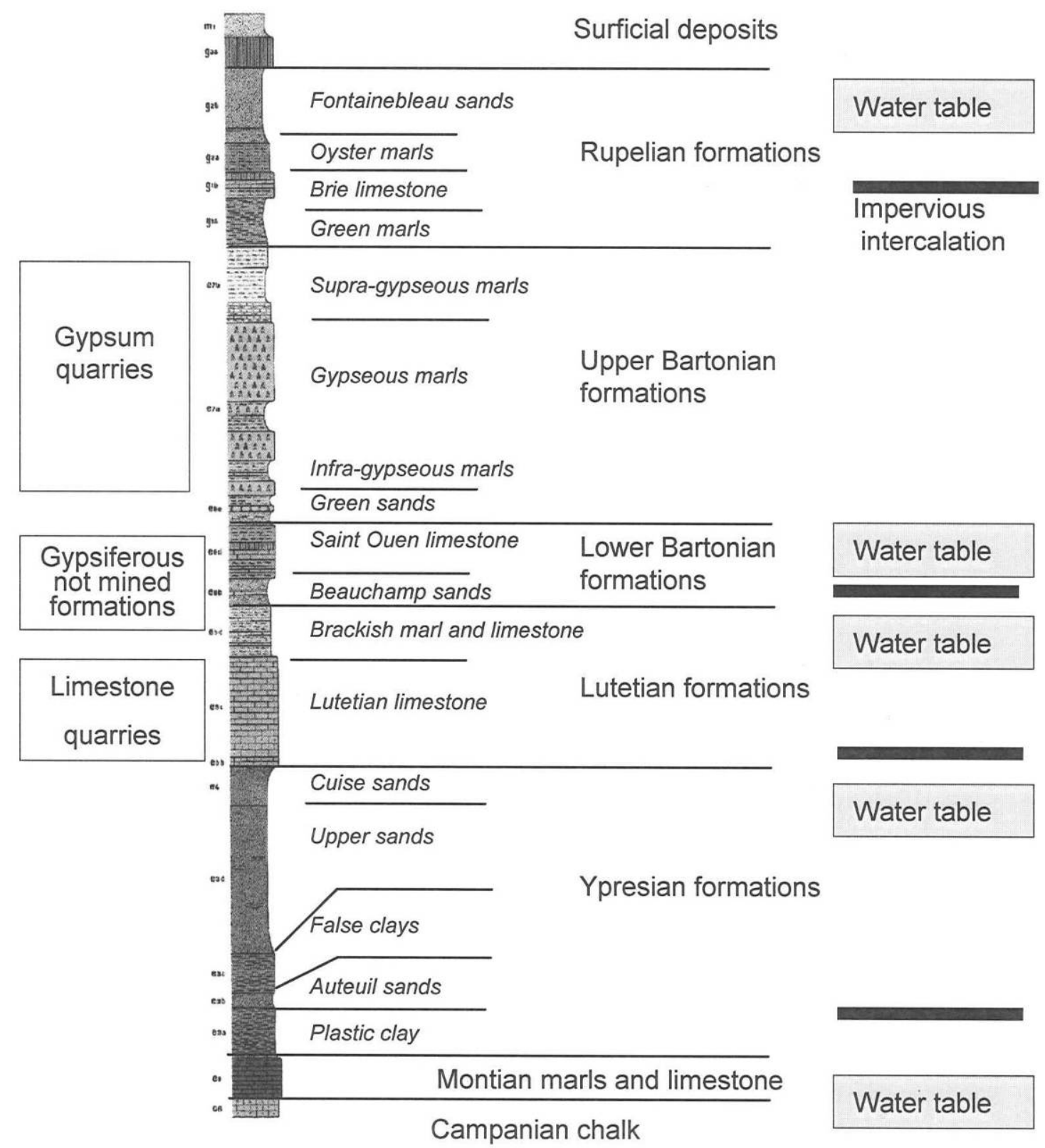

Fig. 1: Simplified stratigraphic column of Paris and main groundwater bodies with associated impervious intercalations

Pre-Ludian formations are likely to develop ground disruptions caused by gypsum dissolution. Three main collapse or subsidence models may be observed (Toulemont 1986): 
progressive subsidence (Fig. 2a), sudden formation of collapse sinkholes (Fig. 2b and 3) and general collapse (Fig. 2c) with overburden's sagging. 
a

Wखy

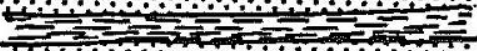
$\because \because \because \because \because \because \cdots 9 \because \cdots \cdots \cdots$

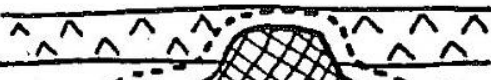

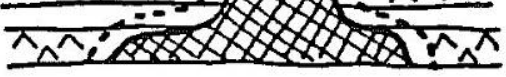

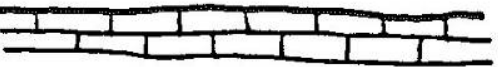

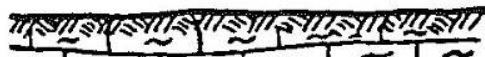

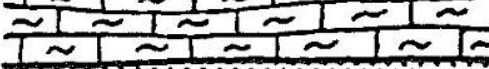

a d o d

F

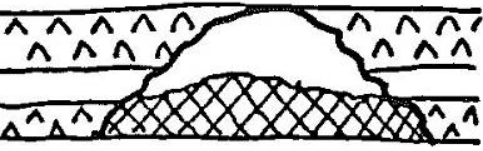

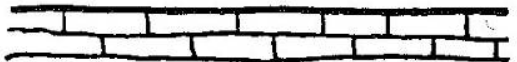

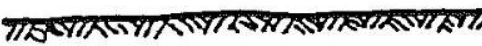
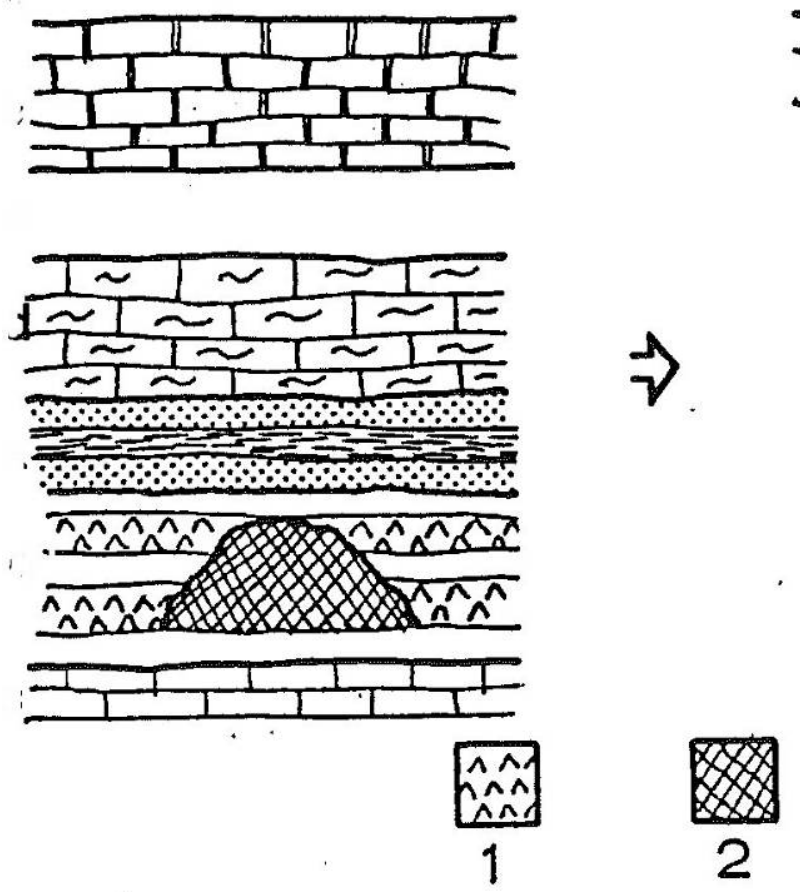

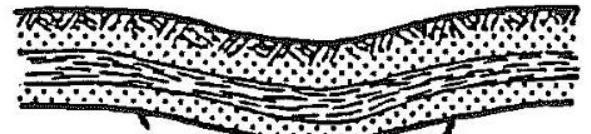

,

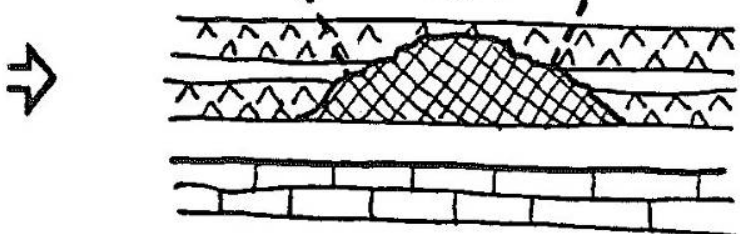

$\stackrel{1}{7}$

b

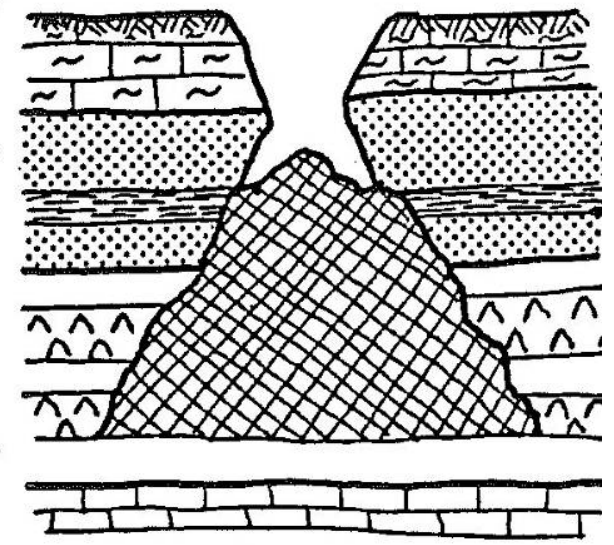

C

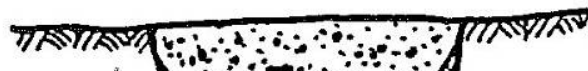

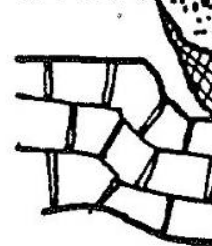
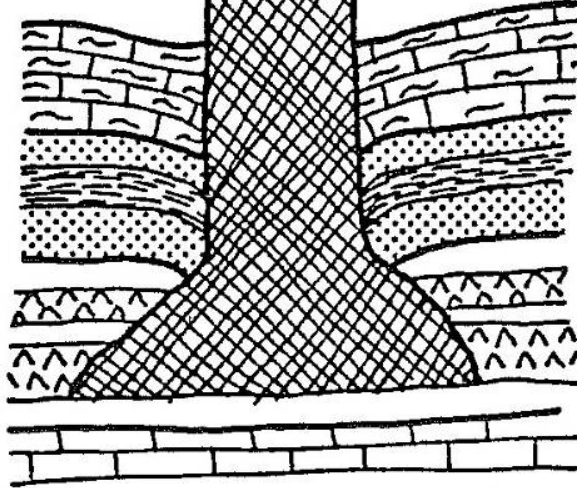
Fig.2: Schematic models of pre-Ludian gypsum dissolution collapse in Paris (in Toulemont 1986)

\section{1: gypseous formation, 2: collapse breccias}

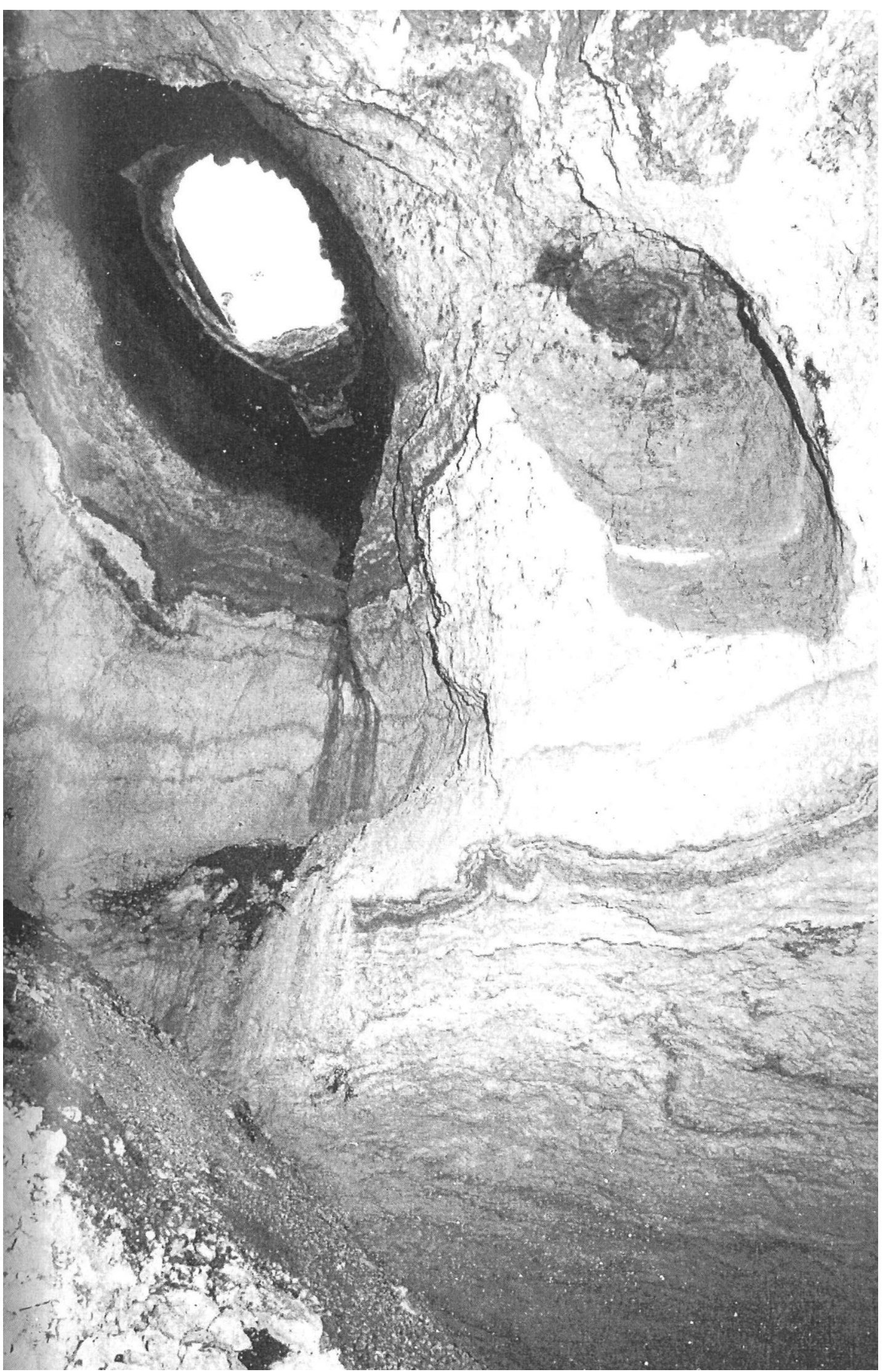


Fig.3: Dissolution collapse in pre-Ludian formation (photo Henrot)

The gypsum of the three concerned formations, initially present near the surface, has been dissolved long time before urbanisation (Toulemont 1986). In addition, existing gypsum beds are now ten meters or more below the surface and they are mainly known only through borehole descriptions. As these boreholes are either for geotechnical purposes or for groundwater research, the associated descriptions of the gypsum beds are, most of the time, very general. In this context, the behaviour of pre-Ludian formations with respect of gypsum dissolution is poorly known and identifying areas susceptible to ground movement related to these formations is a major issue for the city. Work on this topic began several years ago (Deveughele and Usseglio Polatera, 1979). It resulted in a regulation map, i.e. a subsidence susceptibility zoning with legal implications, that was established in 1977 (Order of the Prefect of 25th February 1977) and extended in 2000 (integrated in the statutory PLU (Plan Local d'Urbanisme) of the city of Paris). This regulation map is presented in figure 4, with the administrative limits of Parisian districts (arrondissements).

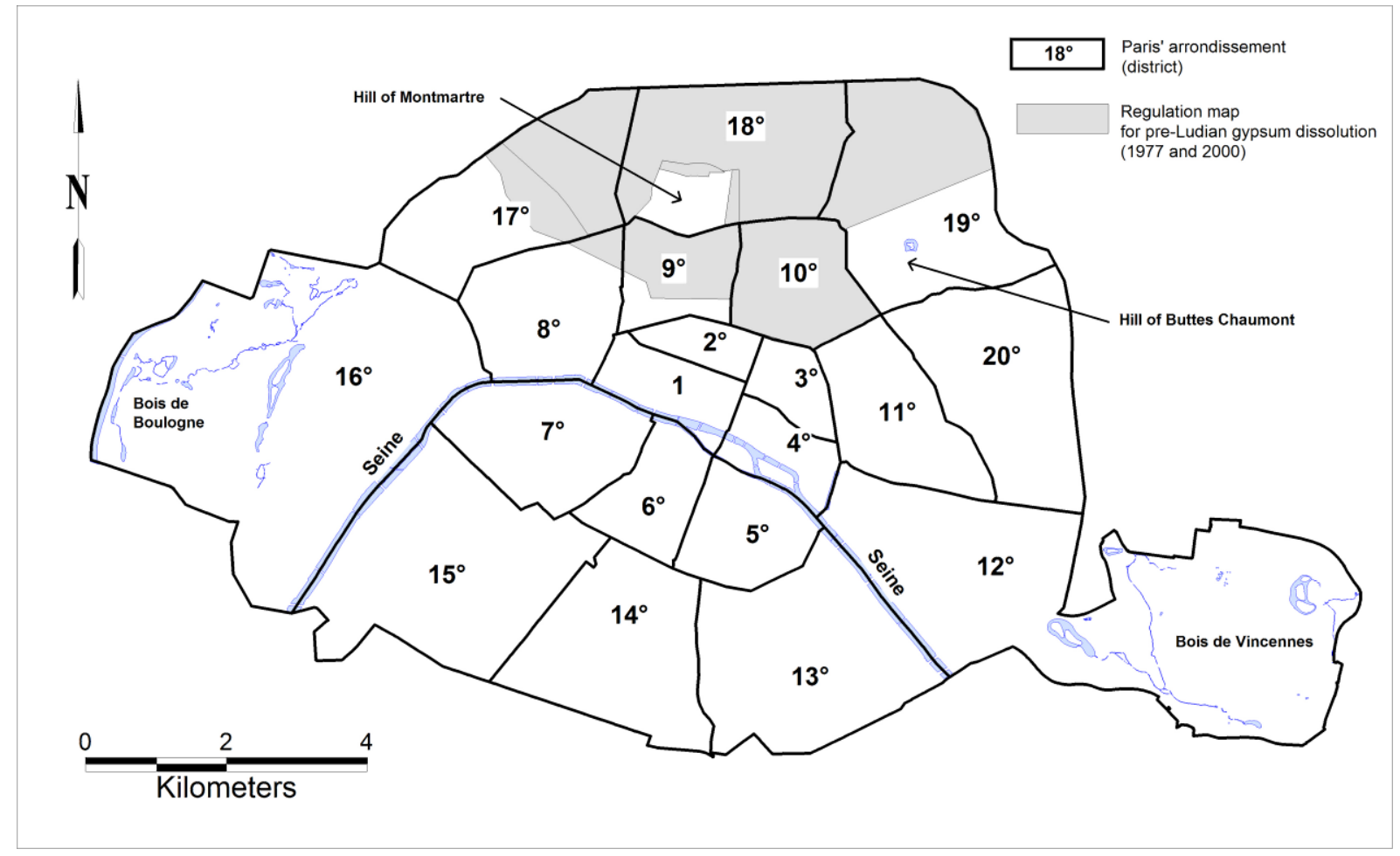

Fig. 4: Administrative limits of Parisian districts (arrondissements) and regulation map for pre-Ludian gypsum dissolution 
However, with a city that covers an area of $105 \mathrm{~km}^{2}$, the authorities have felt the need to establish more accurate boundaries of the areas prone to this problem. This led us to develop a new method based on the construction of a city-scale 3D geological model.

\section{The mapping method}

IGC (Inspection Générale des Carrières), being in charge of ground-related issues in Paris, develops a data base of all incidents related to ground movements. In this database, 647 incidents are currently recorded as sinkholes, subsidences, cracks, landslides, old pits or excavations. This information was used to produce the regulation map in 1977 and 2000 . Moreover, it must be emphasised that it is often difficult to determine the precise cause of ground disruptions which can be related to: compaction over artificially filled quarries, dissolution induced subsidence, building deficiencies, underground working failures, subsidences related to water pumping, clay creeping or swelling. Therefore, localisation of damages which may be related to undefined causes is not really suitable for susceptibility mapping. On the other hand, disruption due to "gypsum dissolution" may be controlled by multiple contributing factors (Galve et al. 2008). For Paris, however, most of these factors are nearly inaccessible, largely due to the urbanisation e.g. man-made disturbances of geomorphology, geology, hydrogeology or hydrochemistry. Moreover, due to budget and time limitations, new data was not collected and only boreholes information or geological maps were used. Mapping ground movement's susceptibility requires analysis of three components and an assessment of their probabilities:

- Probability of the presence of gypsum $\left(P_{p}\right)$ : this involves determining the areas underlain by gypsum of sufficient thickness, e.g. $1 \mathrm{~m}$, to enable the formation of cavities. From this standpoint, it has been established for the main pre-Ludian formations that the thickness of gypsum is related directly to the local thickness of the formation (Toulemont, 1986);

- Probability of dissolution $\left(\mathrm{P}_{\mathrm{d}}\right)$ : it is also necessary that the gypsiferous layers are able to be dissolved, with the formation of cavities likely to lead to collapse (Marteau, 1993). This 
requires the presence of an $\mathrm{SO}_{4}{ }^{--}$-undersaturated water flow over a sufficiently long period of time;

- Probability of collapse or subsidence $\left(P_{c}\right)$ : the appearance of movement at the surface also implies a geological situation (thickness and nature of the overburden) favouring deformation (sagging or collapse) of the cavity roof and propagation of the phenomenon to the surface.

These three probability components, each expressed by a value between 0 and 1 , are then combined to determine the susceptibility (S) of the considered formation at a specific site using the equation:

$$
S=P_{p}^{*} P_{d} * P_{c}
$$

The final susceptibility map is then drawn up by defining S-value categories. Thresholds are based on the distribution of the values through histogram's analysis. These categories correspond to four levels of susceptibility (negligible, low, moderate and high). A separate map is produced for each considered formation.

To establish and map the determining parameters of the three components, therefore, one must be able to evaluate the thickness, depth and nature of the overburden of the three formations concerned at all points of the city, and also assess the hydrogeologic conditions of these formations along with their temporal variations. The first step is achieved by constructing a 3D geological model representing the various formations. The second stage involves determining the water level fluctuations in the different phreatic groundwater bodies below Paris using the highest and lowest water levels (see fig. 5) and the periods during which these characteristics were perennial. 


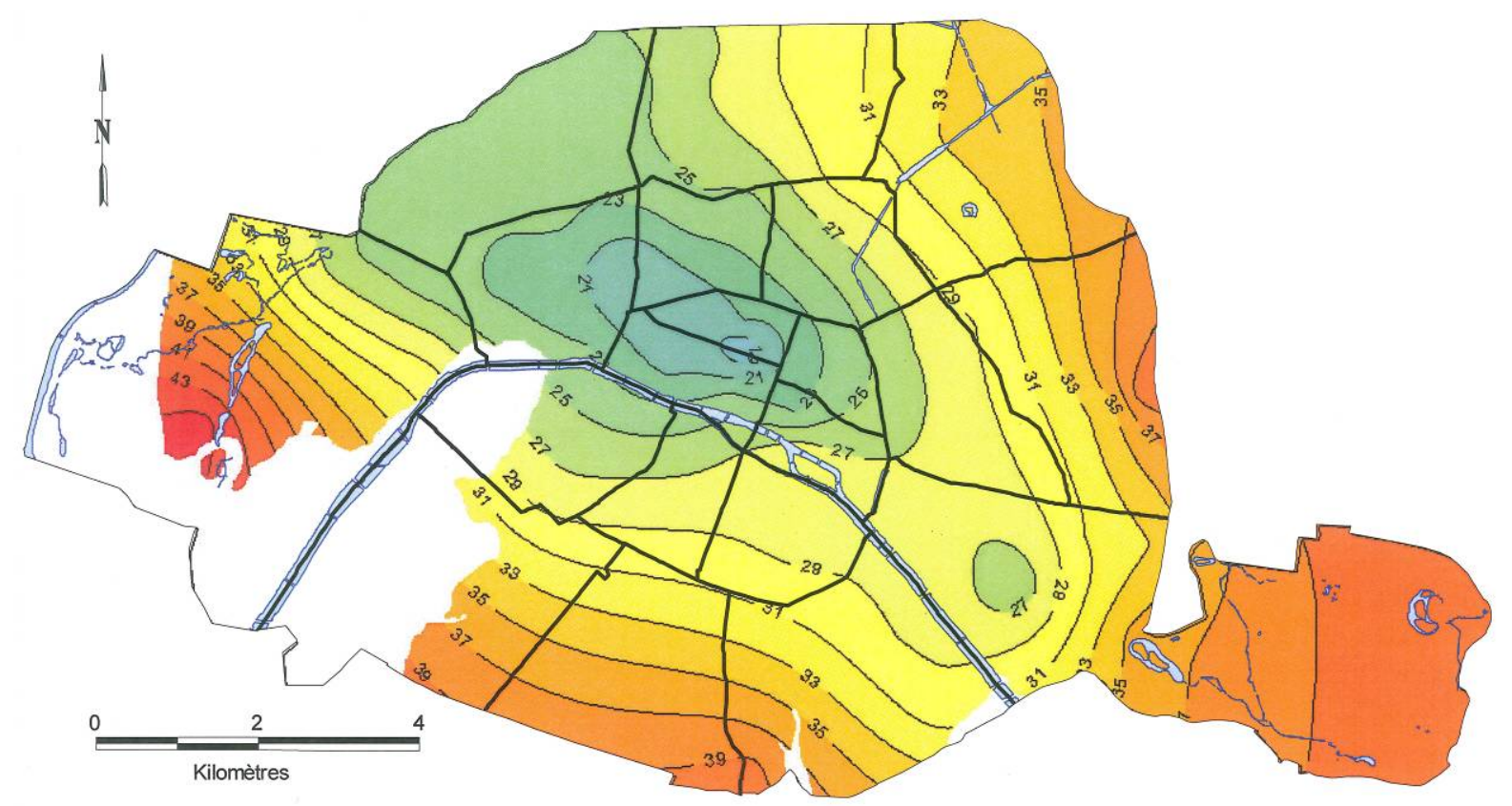

Fig. 5: Highest water level of the Lutetian groundwater body (isolines indicate elevation)

\subsection{The Paris situation}

\subsubsection{Geology}

Many authors have described the geology of Paris (Soyer, 1953; Broquet, 1976; Mégnien, 1980; Usseglio-Polatera, 1980; Toulemont, 1986; Prunier-Leparmentier, 1988), the main features of which are summarized below.

\section{a) Surficial deposits}

Because of intense recent human activity and the various glacial and interglacial environmental conditions that influenced the aggradation of the Seine during the Quaternary, most of the formations exposed in Paris are surficial deposits subdivided into five main types: anthropogenic fill, silt and loess, scree and colluvium, recent alluvium and old alluvium (see Fig. 6 below).

\section{b) Tertiary succession}


The Tertiary succession that makes up the subsurface of Paris is $200 \mathrm{~m}$ thick below the hill of Montmartre (120 m above sea level). This large thickness is due to the combined effect of the topography and the deepening of the Paris' northward dip of the strata (Saint Denis trough). It comprises, from top to bottom:

i) The youngest rocks, at the top, are made up of residual Fontainebleau Sands [Sables de Fontainebleau]. These rest on a marly and argillaceous unit some $60 \mathrm{~m}$ thick made up of different formation: Oyster marl [Marnes à huîtres], Brie Limestone and Travertine [Calcaires et Travertins de Brie], Green marl [Marnes vertes], Supra- and infra-gypseous marl [Marnes supra et infra gypseuses], in which four gypsum beds, between 5 and $20 \mathrm{~m}$ thick, are intercalated. The thickest beds have been mined mainly in the north (Montmartre) and east (Buttes Chaumont) of Paris. The base of the gypsum is marked by a relatively thin ( 0.5 to $3.0 \mathrm{~m}$ ) layer of Green Sand [Sables Verts].

ii) The Bartonian, represented by the Saint Ouen Limestone some $10 \mathrm{~m}$ thick, makes up the base of the hills of Montmartre and Buttes Chaumont. It is an alternation of calcareous, marly and argillaceous, possibly gypsiferous, beds. The Saint Ouen Limestone overlies the Auversian sands (Beauchamp Sands) some $10 \mathrm{~m}$ thick and then Lutetian limestone.

iii) The Lutetian makes up most of the Paris bedrocks. A maximum of $60 \mathrm{~m}$ thick, it comprises two members:

- (1) an upper member of "Brackish Marl and Limestone", 7 to $35 \mathrm{~m}$ thick. This comprises an alternation of white magnesian marl, dolomite and limestone. The greater thickness of this formation is generally associated with the presence of gypsum beds. This gypsum has not been mined;

- (2) a lower member, 15 to 25 m thick, consisting of the Lutetian Limestone [Calcaire Grossier] exploited from Roman times until 1813. Excavations were performed in the subsurface of Paris over an area of 770 hectares corresponding to the dewatered and thus 
structurally high zones in the west (Bois de Boulogne) and east (Bois de Vincennes) of Paris and to the south of the meander of the Seine river.

iv) The Ypresian formations, between 40 and $75 \mathrm{~m}$ thick (underlying the Lutetian). The upper part consists of the Soissonnais Sands [Sables du Soissonnais] from 4 to $10 \mathrm{~m}$ thick and comprising the Cuise Sands [Sables de Cuise] and the Upper Sands [Sables Supérieurs]. They rest on a thick $(30 \mathrm{~m})$ generally clayey member (False Clays [Fausses Glaises], Auteuil Sands [Sables d'Auteuil] and Plastic Clay [Argile Plastique]).

c) The Campanian Chalk is the youngest formation of the Mesozoic substratum. It is locally overlain by the Montian marls and limestone.

Regarding the gypsum in the non-exploited formations, one notes that in the:

- Saint-Ouen Marl-Limestone: the gypsum occurs as thin layers, several centimetres thick, intercalated between limestone or marl beds, and in places as residual lenses. This configuration does not enable large karstic voids to develop, and so excludes the formation of significant sinkholes. The instabilities correspond primarily to gradual sagging up to the surface (see fig. 2);

- Beauchamp Sands: gypsum beds up to about $1 \mathrm{~m}$ thick can be present within the formation. The associated karsts features are small;

- Brackish Marl and Limestone: this is by far the most problematic formation as regards the collapse of karstic voids. In the areas where the formation is more than $30 \mathrm{~m}$ thick, the cumulative thickness of massive gypsum beds can be as thick as $15 \mathrm{~m}$. Large karstic voids are present in this unit (e.g. large cavities encountered below the Gare du Nord (Moynot 1977)), and eventually cause major surface disruptions including sudden collapse sinkholes.

\subsubsection{Hydrogeology}


The hydrogeology of Paris is extremely complex (Diffre, 1969; Prunier-Leparmentier, 1988, 1991). Many of the geological formations present below Paris are aquiferous units. But, insofar as these layers are not everywhere separated by impervious intercalations (only the Ypresian Plastic Clay and the Sannoisian Green Marl are considered as impervious formations), we are generally dealing with groundwater in a multi-layer aquifer that, at the scale of Paris and for the studies made there, is considered as a set of individual aquifers. Five main aquifer units can be differentiated: Quaternary alluvium, Saint Ouen/Beauchamp (or Bartonian), Lutetian, Ypresian and Chalk units, plus two Oligocene perched aquifers in the north of Paris, hills of Montmartre and Buttes Chaumont (see Fig 5 and 6).

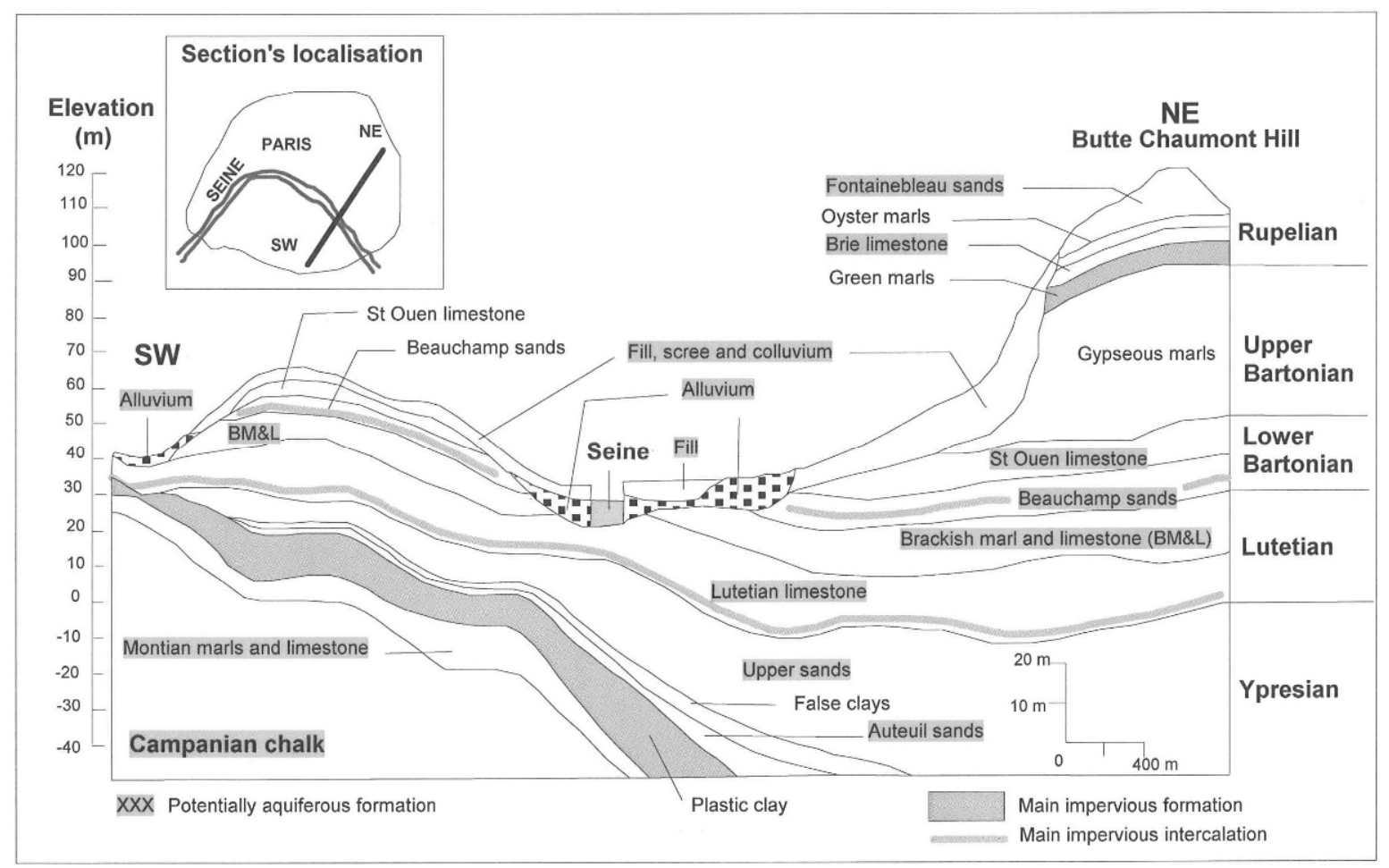

Fig. 6: Schematic geological section in Paris with main hydrogeological features

The Upper Eocene multi-layer aquifer includes four formations likely to contain groundwater. It contains a specific groundwater body located in the Beauchamp Sands and Saint Ouen Marl-Limestone. This body is relatively isolated from the Lutetian groundwater by the clayey 
beds of the Beauchamp Sands. The groundwater contained in the Bartonian beds is unconfined in the northern parts of Paris, i.e. the 17 th, 18 th, 19 th and $20^{\text {th }}$ districts.

The Lutetian and Ypresian aquifers can be separated by a sandstone layer present at the base of the Lutetian Limestone or locally by the Laon Clay (Argile de Laon), locally present as isolated patches on the right bank of the Seine, but absent in the left bank. From the hydrodynamic standpoint, these two groundwater bodies have different piezometric levels where the Seine passes through the centre of Paris. The Ypresian formations contain two aquifers separated by the False Clays; the Auteuil Sands and the Cuise Sands where these are present. The groundwater in the Ypresian aquifer is generally confined except in the districts where the sandy layers disappear to the south (13th, 14th, and 15th districts). In the 16th district, in the west, the Auteuil Sands aquifer is confined where the aquifer is not exposed. The piezometric level of the Ypresian aquifer's static level is close to, but different from, that of the Lutetian aquifer, except in the north where there is a very slow inter-aquifer transfer of water (see section in fig.5). This phenomenon is accentuated by pumping.

As far as the gypsum dissolution process is concerned, we have only considered the groundwater bodies likely to have an impact on this process. This involves: the Saint Ouen/Beauchamp and the Lutetian aquifers.

\section{Construction of a 3D geological model}

Geological data, of urban areas in geographical information systems (GIS), are generally under-represented (Easa and Chan, 2000). As for 3D modelling, despite various experiences of geological modelling in urban environments (Maurenbrecher and Herbschleb, 1995; Ellison et al., 1996; Morfeldt and Persson, 1997; Bozzano et al., 1999; Thierry et al., 2000; Auvinet et al., 2001; De Rienzo and Nardi, 2004, De Rienzo et al. 2008), the methods still largely remain to be developed (Appel, 2006). A recently developed method using borehole descriptions (Bourgine et al., 2006) is based on the use of geostatistical tools (Chilès and Blanchin, 1995; Chilès and Delfiner, 1999; Aug, 2004). 
Construction by this geostatistical method is through interpolating the bottom and top surfaces of the modelled geological formations from available borehole data and compiled geological maps. The main difficulties in this type of construction arise, in part, from the large amount of data to be processed (several thousand boreholes) and, in part, from the very heterogeneous level of precision in the descriptions and locations. Therefore, in order to obtain a consistent and reliable result, it is absolutely essential to develop tools to check data and verify their reliability.

\subsection{Geological frame of reference}

The first stage in constructing a 3D geological model aims at defining a geological frame of reference to be able to determine the geological and hydrogeological parameters that control the development of hazardous processes. This frame of reference must group the lithostratigraphic formations into large homogeneous units as far as their mechanical and hydrologic behaviours are concerned. For the model of Paris, the frame of reference comprises 21 lithostratigraphic units which; from the top to the bottom are: Fill and topsoil $\left(T_{R E}^{*}\right)$, Scree, loess, tableland loam, colluvium (EBOL), Recent alluvium (ALUM), Old alluvium (ALUA), Fontainebleau Sands (FONT), Brie Limestone, Oyster marl (BRIE), Green marl and clay (MAVE), Supragypseous marl (MSGY), Gypsum beds and marl (MGYP), Infragypseous marl (MIGY), Greensand (SVER), Saint Ouen Limestone and Ducy Limestone (OUEN), Beauchamp Sands (BCHA), Brackish Marl and Limestone (CAIL), Lutetian Limestone (CGRO), Soissonais sands and Cuise sands (SYPR), False Clays (FGLA), Auteuil Sands (AUTE), Plastic Clays and Meudon Conglomerate (APLA), Meudon Limestone and Marl (DAMO) and Chalk (CRAI).

\subsection{Input data and controls}

\footnotetext{
* The abbreviations are those used on the map and refer to the French unit; thus TVRE is obtained from "Terre végétale and remblais", etc.
} 


\subsubsection{Input data}

A digital elevation model (DEM) with a $20 \times 20$ m mesh was generated from the levelling data provided by the City of Paris. The precision in elevation of this DEM is of the order of one metre. After discarding doubtful drilling, the various archives contained 3,927 boreholes described through 49,994 strata sections (runs), which were used for the modelling. The boreholes were selected to cover the entire city with a spacing of no more than $200 \mathrm{~m}$ from any point of information. The descriptions of these boreholes are recorded in a database (MS ACCESS) where each record corresponds to a borehole run. Each borehole is described by a succession of sections each of which corresponds to a lithological or stratigraphic layer. The main fields that had to be filled in were:

- $\quad$ the borehole identifier;

- the borehole's $\mathrm{X}, \mathrm{Y}, \mathrm{Z}$ coordinates;

- the downhole depth of the run end;

- the lithostratigraphic frame of reference code of each run.

Figure 7 shows the distribution of the boreholes used for the study. Two zones that remain under-sampled correspond respectively to the Bois de Boulogne and Bois de Vincennes, where very few investigations have been carried out since they are public parks. 


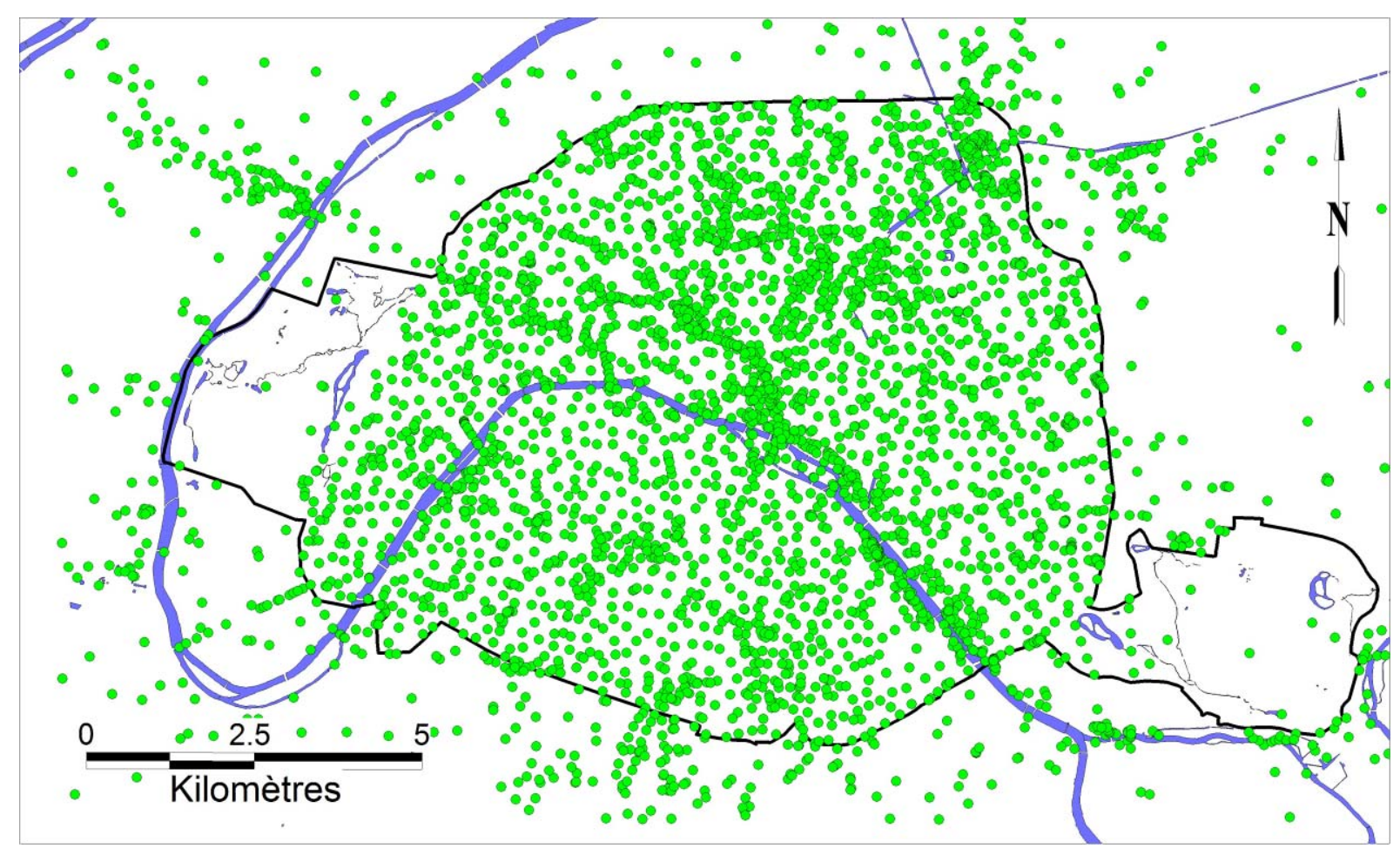

Fig. 7: Distribution of the boreholes used for the study

Two map sources were also used for modelling:

- the IGC Geological Atlas at 1:5,000 scale

- the BRGM 1:25,000-scale geological map for the Bois de Boulogne and Bois de Vincennes areas not covered by the Geological Atlas.

These maps were used for digitizing the boundaries of reference lithostratigraphic units. At this step, the boundaries could locally be modified according to the information provided by the boreholes. The availability of these boundaries makes it possible on the one hand to provide passage points to constrain the interpolated surfaces, and on the other hand to limit the interpolations to the zones where the different units are actually present.

\subsubsection{Controls}

The generation and handling of so much data cannot be undertaken without systematic controls aimed at minimizing the number of errors (typing errors, interpretation errors, etc.) 
and verifying the consistency of the data. It is an essential phase in this type of study. The following controls were thus systematically carried out:

- Identification of duplicated boreholes.

- Comparison of borehole elevation against the DEM.

- Checking the validity of each borehole's description. A first analysis enabled a systematic check to ensure that: (i) the codes used corresponded to those retained in the frame of reference and (ii) the descriptions contained no aberrant superpositions (e.g. a Tertiary formation overlying Quaternary alluvium).

- Analysis of the interfaces' coherence in comparison with the geological boundaries. It is also systematically verified that all the formations observed in each borehole correspond to a plausible geological context (e.g. recent Quaternary alluvium must not be found on the top of hills and atypical thicknesses should be avoided).

- Comparison between neighbouring boreholes lying no farther apart than a quarter of the model's mesh (i.e. $5 \mathrm{~m}$ in our study). Here one is looking for boreholes showing a similarity percentage of less than $90 \%$, and/or a difference of more than $5 \mathrm{~m}$ in formation thickness or in altitude of equivalent interfaces.

All detected inconsistencies were examined. Where no correction was possible, the borehole was discarded. Following this, around 1,400 boreholes were checked, from which around 700 boreholes were corrected and 30 discarded.

\subsection{Geostatistical interpolations}

The initial step of the analysis concerns the distribution of values (histogram) and a variogram analysis which enables us to calculate the correlation loss as a function of the distance between two boreholes. Construction of the digital model involves interpolation of 
the parameters at the nodes of a regular grid through kriging (Chilès and Delfiner, 1999). This interpolation makes it possible to calculate:

- the level of the top of the formation

- the thickness of the formation;

- the level of the bottom of the formation is then obtained by simple numerical processing: level of the bottom $=$ [level of the top $]-$ [thickness $]$.

Compared to other methods of automatic interpolation, kriging has the advantage of associating an estimation error with each estimated or interpolated value. This error is used to plot iso-uncertainty curves thus providing a measurement of the precision associated with the interpolated parameter at any point on the map. In practical terms, the pattern of the isouncertainty curves shows how the quality of a map deteriorates as one moves away from factual information or points of information. Another interpolation method (cokriging) could have been applied in this case. However, it does not properly handle non parallel surfaces (erosional surfaces, disconformities) and existing softwares are not designed to treat inequality data.

\subsubsection{Inequality and exact data}

The boreholes provide two types of quite distinct information:

- data known as "exact" (hard data) corresponding to the "true" levels of the tops and bottoms of the formations, and true formation thicknesses

- "inequality" data (soft data) corresponding to the lower and upper limits (min-max thresholds) that could represent the levels of the formation tops and bottoms or the formation thicknesses.

The difficulty consists in obtaining a model that respects both exact and inequality data. The method followed involves the four following stages: 
- The first stage consists in interpolating the variables of interest (top, bottom, thickness) using only the exact data (Fig. 8a).

- The second stage, which is the most delicate, consists in comparing this first model against the inequality data (Fig. 8b). Where one notes a contradiction between the model and the inequalities, a constraining point must be introduced to "force" the model to respect the inequalities (Bourgine et al., 2006). This comparison is done on the basis of a "tolerable" maximum spread, which is nominally fixed according to the intrinsic data error (e.g. an endof-borehole level known to within $1 \mathrm{~m}$ at best) and to the accepted error in the processed variable. Once a constraining point has been introduced, the model is updated with the new data added to the exact data (Fig 8c) and the process is reiterated. In practice, when dealing with several hundreds or thousands of data, one obtains a large number of inequalities that are not respected by the first model. These inequalities could all be translated more-or-less automatically into constraints, but experience shows that it is necessary to proceed iteratively and to manually control the observed spreads, starting with the largest. It is commonly necessary to review certain borehole descriptions and check whether the observed inconsistencies closely correspond to geological realities or whether they are due to keying errors or errors in the initial interpretation of the data (imprecise drilling, erroneous geological boundary, etc.). This iterative phase is long and delicate, but it guarantees the quality of the model and a thorough control of the data.

- The third stage aims at the complete interpolation of all the surfaces from the exact data and the additional constraining points, using the specific geostatistical parameters of each surface or formation.

- The fourth stage consists in combining the various obtained surfaces in order to reconstruct the geological history (phases of deposition and erosion). In general, the formations are logically superimposed following the stratigraphic order. However, in the case of sedimentation gaps or erosion, modelled surfaces are likely to "cross-cut" one another. The logic of combination leads to cut the sedimentation surface with the erosion surface. 


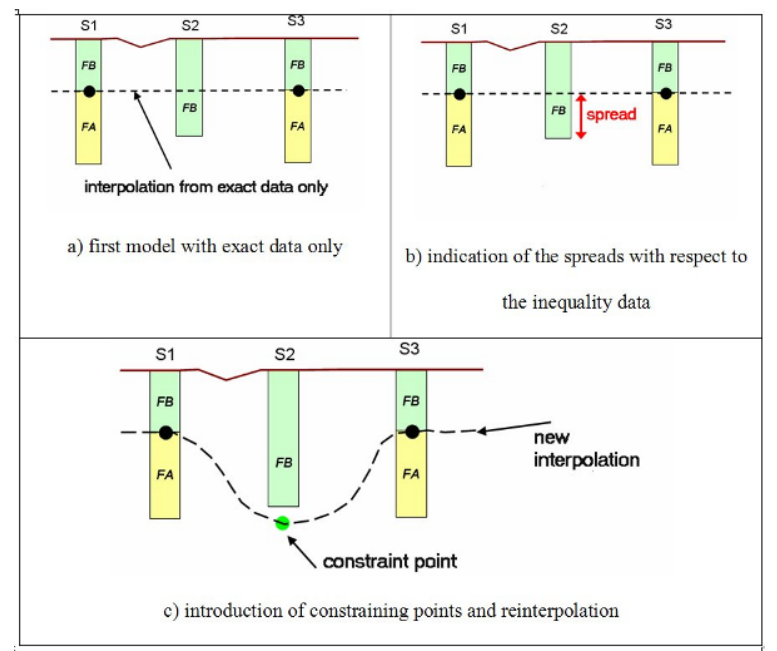

Fig. 8: Phases when taking inequalities into account.

\section{Calculation of the high water (HW) and low water (LW) levels}

About 300 single piezometers, mainly managed by IGC, are installed in Paris. The first phase was to verify the consistency of the data from these piezometers with the geological model. Analysis and correction of the logs were carried out with respect to the study objective, namely determining the relevant multiannual water levels for establishing the dissolution potentialities.

This work consisted of the following steps:

- Eliminating inconsistent data, i.e. those that appear incompatible with the overall pattern of the log. This generally concerns one or more isolated level measurements. The example of the piezometer log given in Figure 9 illustrates the elimination of an isolated point.

- Identifying periods when the piezometer was dry. The actual low water level for these piezometers is unknown, being lower than the bottom level of the hole. The piezometer log of Figure 9 indicates a dry period from March 1995 to October 1997 due to pumping near the piezometer. 
- Identifying periods when the piezometer was subject to the influence of nearby pumping. In natural conditions, gypsum dissolution hardly occurs due to slow groundwater flows remaining saturated with $\mathrm{SO}_{4}{ }^{--}$. Pumping accelerates these processes with water renewal. Gypsum dissolution is influenced by pumping only after a sufficiently long period. Data influenced by short-duration pumping, fixed here at less than 6 months from author's experience, were not taken into account. The piezometer of Figure 9 was influenced by two periods of pumping; one of more than 3 years, the other of approximately 2 years.

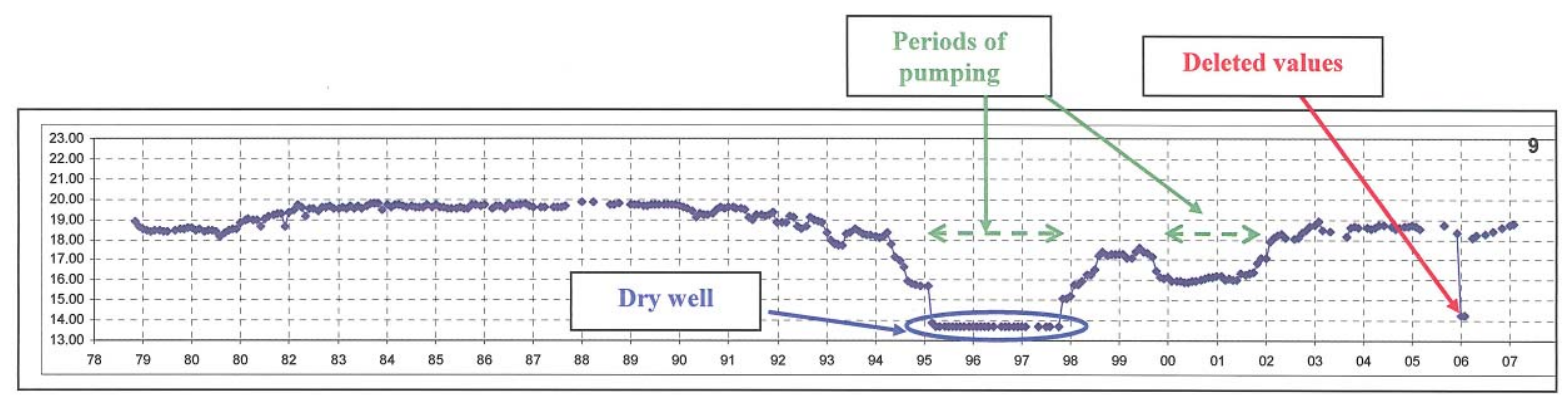

Fig. 9: Impact of periods of pumping on the piezometric level expressed in $m$ NGF (French datum) for the 8th district of Paris.

An additional control of the consistency of these values with the total depth of the borehole and the elevation of the wellhead was also carried out. This consists in checking that the LW value is indeed higher than the bottom level of the well, and that the measured HW value is equal or lower than the altitude of the wellhead. This control was followed, where necessary, by a correction of the data.

Subsequently, the values of the lowest and highest water levels corresponding to the minima and maxima of the piezometric logs were determined for each piezometer.

After analysing all the information related to the piezometers and their logs, 188 piezometers with sufficient information concerning location and water levels of unconfined or confined aquifers were retained for this study. These piezometers were classified according to the confined groundwater and the corresponding HW and LW levels calculated by interpolation. 


\section{Mapping the susceptibility zones}

In this paper, we only describe, as an example, the Brackish Marl and Limestone formation.

\subsection{Determining the probability of the presence of gypsum $\left(P_{p}\right)$}

The gypsum in the Brackish Marl and Limestone (BM\&L) generally occurs as several main beds that may or may not be present:

- at the top of the formation, with a thickness of 1 to $2 \mathrm{~m}$;

- at the base of the formation with a thickness commonly of 3 to $6 \mathrm{~m}$, which is locally largely exceeded (up to $10 \mathrm{~m}$ ).

Earlier work (Arnoult and Le Guillou, 1967; Toulemont, 1986) shows a good relationship between the thicknesses of the Brackish Marl and Limestone (BM\&L) and that of these gypsum beds, as shown in Figure 10. These authors proposed the following regression equation: $y=0.39 x-429.01$ with a coefficient of variation $R$ of 0.60 and between 0.473 and 0.702 for confidence limits of $95 \%$. These authors proposed that gypsum becomes present when the BM\&L thickness exceeds $12 \mathrm{~m}$. They also considered that any thickness above 20 $m$ is, in theory, due to the presence of gypsum. 


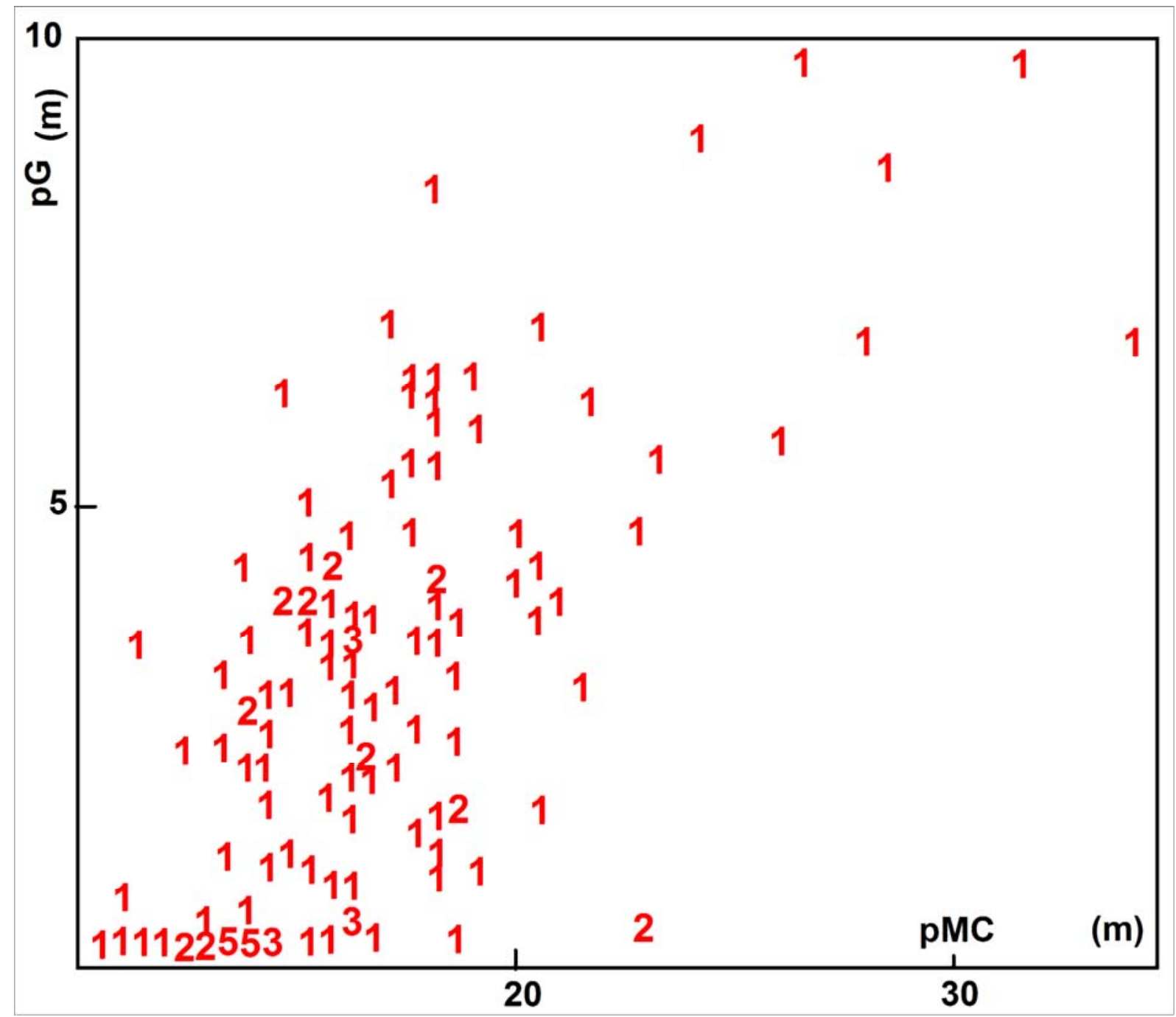

Fig.10: Statistical correlation between BM\&L thickness ( $p G$ ) and gypsum beds cumulated thickness (pMC) from 129 observations (from Toulemont 1986).

Based on this relationship we have considered that:

\begin{tabular}{|l|l|}
\hline BM\&L from 0 to $15 \mathrm{~m}$ thick & no or very little gypsum \\
\hline BM\&L from 15 to $20 \mathrm{~m}$ thick & increasing thickness of gypsum \\
\hline BM\&L over $20 \mathrm{~m}$ thick & "maximum" thickness of gypsum \\
\hline
\end{tabular}

This situation is represented in Figure 11, where the probable presence of gypsum $\left(P_{p}\right)$ in terms of thickness is expressed by a value of between 0 and 1 . The initial value is fixed at 0 , insofar as the absence of gypsum gives a probability of zero. 


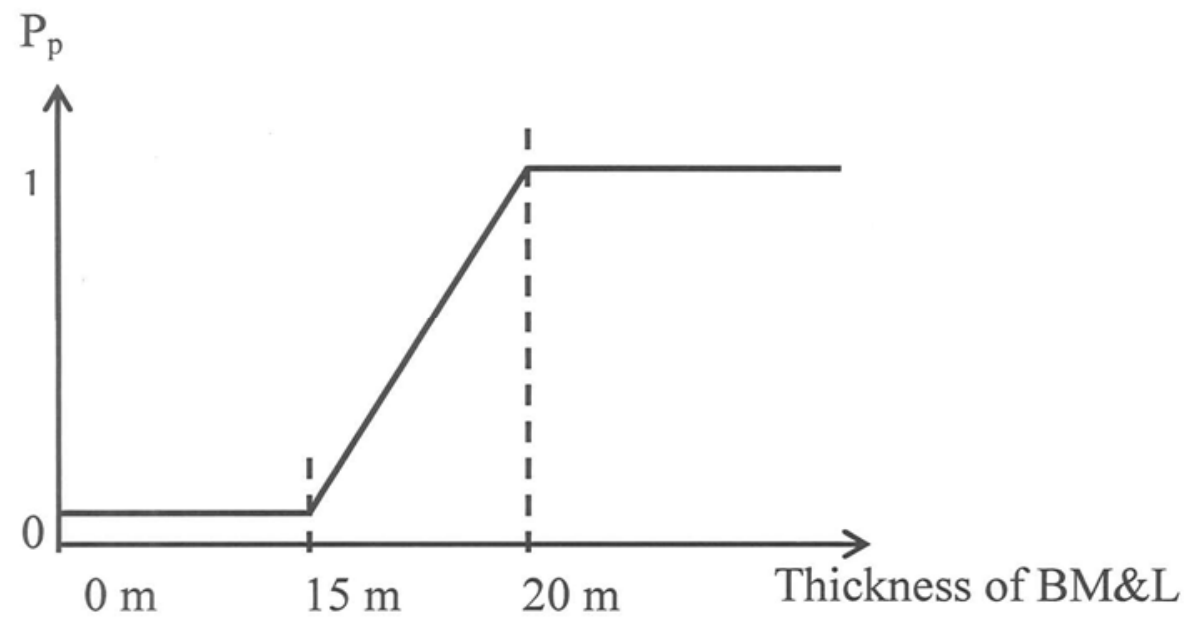

Fig.11: Relationship between formation thickness and presence of gypsum probability for the Brackish Marl and Limestone.

For a formation thickness between 15 and $20 \mathrm{~m}$ ( $5 \mathrm{~m}$ spread), the probability of the presence of gypsum $\left(P_{p}\right)$ is obtained by the equation:

$P_{\mathrm{p}}=\left(T h_{B M \& L}-15\right) / 5$ where $T h_{B M \& L}=$ Total thickness of the Brackish Marl and Limestone Figure 12 shows the result of such processing.

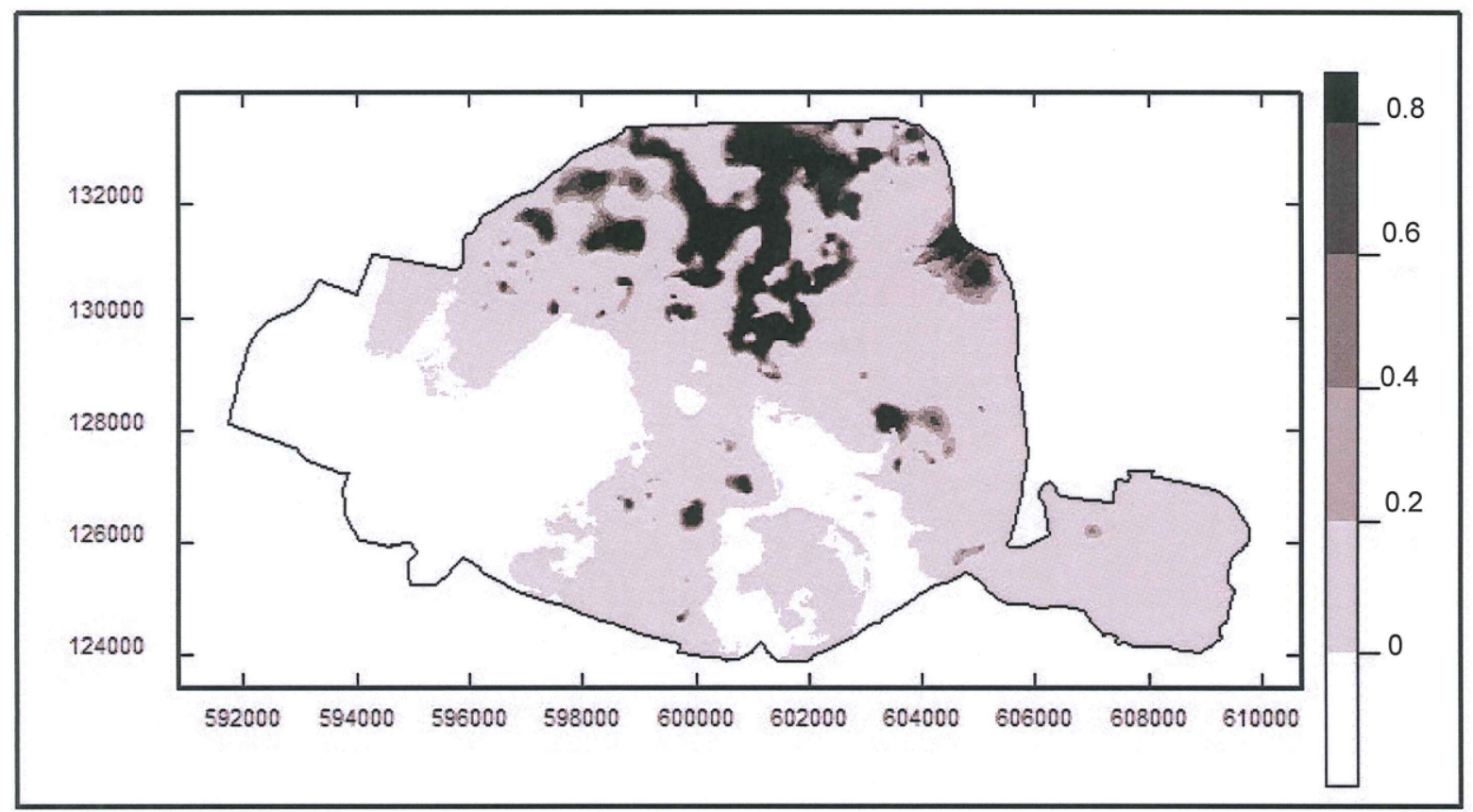

Fig. 12: Probability of the presence of gypsum in the Brackish Marl and Limestone 


\subsection{Determining the probability of dissolution $\left(P_{d}\right)$}

Gypsum dissolution may occur if the rock interacts with water unsaturated with respect to this mineral. Dissolution occurs where the $\mathrm{SO}_{4}^{--}$-saturated water is renewed with unsaturated water over a sufficiently long period (several monthes). Among others, two factors will then govern dissolution:

- the position of the gypsiferous formation with respect to the relative groundwater level;

- the value of the hydraulic gradient associated with the lowest water (LW) level, which best reflects the past influence of pumping on the water circulation and its renewal, without impinging on the future evolution of water levels due to climatic change or modifications in water policy.

Mapping the probability of dissolution $\left(P_{d}\right)$ is based on the low-water gradient determined from analysis of the IGC piezometers. Hydrochemistry and composition of gypsum beds constitute other important factors controlling dissolution. Unfortunately they are known only at individual points and at one moment. Therefore, these factors can hardly be used to build a mapping at the city scale. The average gradient is calculated using a $20-\mathrm{m}$ mesh to allow crossing with the two other probabilities (presence of gypsum and collapse).

Figure 13 shows the results obtained for mapping the LW gradients of the Lutetian groundwater. The values vary from 0 to $3.27 \%$. The particularly high value of the Lutetian groundwater gradient $(3.27 \%)$ is very localized; it is notably the result of measuring a very sizeable groundwater drawdown on a piezometer installed by the SNCF (the French railways company) to monitor specific work. 


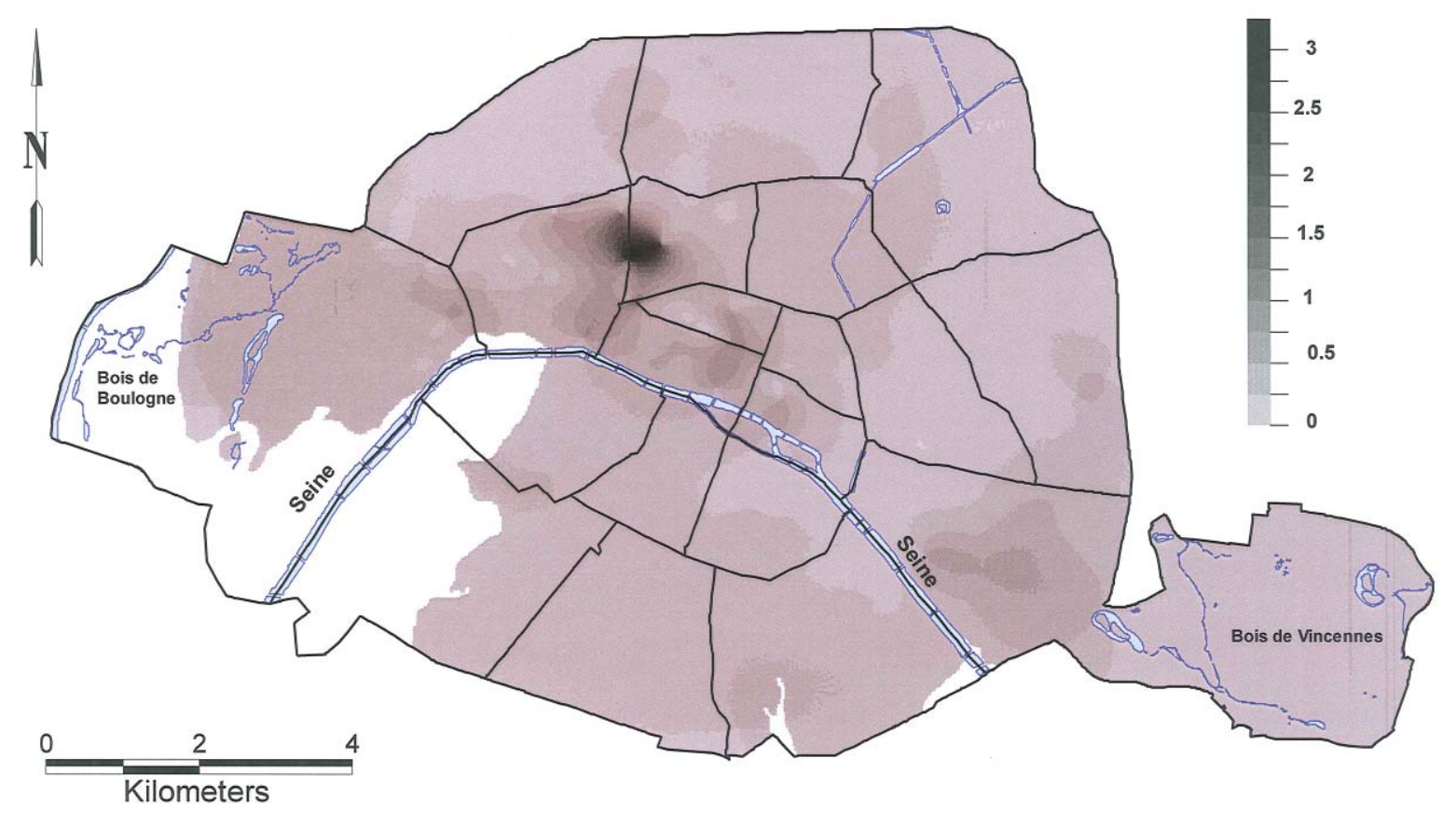

Fig. 13: LW gradient of the Lutetian groundwater.

The probability of dissolution $\left(P_{d}\right)$, based on the local gradient value, is expressed by a value ranging between 0.1 and 1 . The initial value is not fixed at 0 insofar as, regardless of the position of the gypsiferous formation, it is difficult to regard the possibility of dissolution as non-existent. The limiting value of 0.1 (low probability) is used when the gypsiferous formation is:

- located outside of the groundwater, i.e. the base $(B x)$ is located above the high water (HW) level. In this respect, urban waterproofing reduces vadose flows;

- located below the water level fluctuations region: in this case, the top (Tx) is located below the low water (LW) level. In this case, the LW level considered is the calculated LW level decreased by a margin; this margin allows water circulation in the upper part of the groundwater to be taken into account. It is fixed at $25 \mathrm{~m}$ based on actual situations encountered in Paris.

The probability of dissolution $\left(P_{d}\right)$ in the water level fluctuations region varies from 0.3 to 1 (moderate to high probability). It is considered that, regardless of the gradient, the probability of dissolution is high in an area located within the water-level-fluctuations region. Thus the 
value 1 corresponds to the maximum observed gradient value and the value 0.3 to the minimum gradient. The method of calculation is outlined in Figure 14.

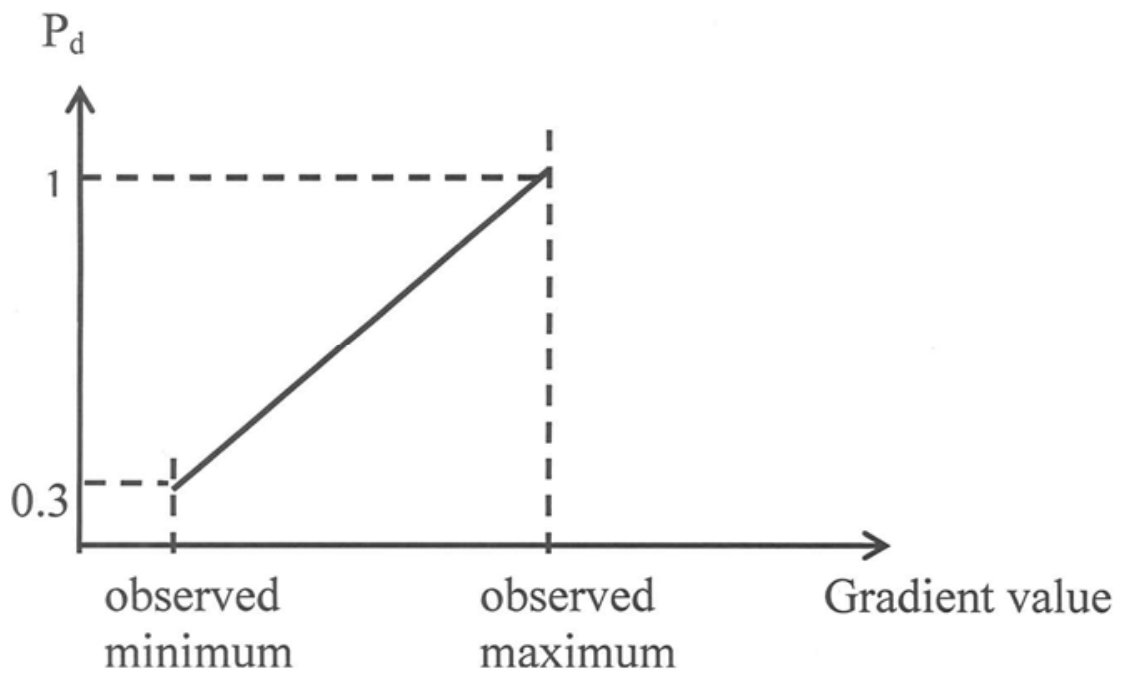

Fig. 14: Method of determining the probability of dissolution for a formation located in the groundwater level fluctuation region.

The probability of dissolution in the water level fluctuations region is thus a function of the gradient according to the formula:

$$
P d=1-((1-0.3)(\max -G) /(\max -\min ))
$$

where $G=$ local value of the gradient

$\max =$ maximum value of the observed groundwater gradient

$\min =$ minimum value of the observed groundwater gradient

\subsection{Probability of collapse and damage $\left(P_{c}\right)$}

Two factors must be taken into account that can either decrease the probability of subsidence, or aggravate it:

- the thickness of the overburden: beyond a certain depth, a thick overburden will decrease the probability of the collapse reaching the surface, either because of self- 
blocking mechanisms or by having sufficient mechanical qualities to halt the progression of collapse towards the surface (which, in particular, is the case for the Saint Ouen Limestone);

- conversely, water saturation can contribute to a decrease in the mechanical strength of stratigraphic layers, which is likely to increase the probability of roof failure of cavities and significantly aggravate the development of sinkholes.

In the first instance, therefore, the probability of collapse $\left(P_{c}\right)$ will be inverse to the thickness of the overburden of the considered formation, which is determined by the equation:

$$
\begin{aligned}
& T h_{0}=\text { Topo }-T_{x} \\
& \text { where } T h_{0}=\text { thickness of the overburden } \\
& \text { Topo = elevation of the topographic surface } \\
& T_{x}=\text { elevation of the top of formation } x
\end{aligned}
$$

It is also considered that a very thick overburden, here estimated at $80 \mathrm{~m}$, considerably reduces the probability of collapse at the surface. In such cases, the $\mathrm{P}_{c}$ component of the disruption susceptibility is regarded as null $\left(P_{c}=0\right)$.

In the case of the Brackish Marl and Limestone, the thickness of the Beauchamp Sands, which are not likely to influence the evolution of the phenomena due to their low tensile strength, is subtracted from the total thickness $T_{0}$.

In the second instance, the influence of water saturation is very difficult to take into account. One can estimate that saturation decreases the rock mechanical quality by approximately $30 \%$. This is an average value, compatible with the available data on the evolution of the mechanical strength of limestone with water saturation (Dessandier, 1995; Duperret et al., 2005, Ghabezloo and Pouya, 2006). It must be noticed that, conversely, water saturation reduces the effective weight of stratigraphic layers due to buoyancy. We have considered that the influence of this reduction in mechanical quality is more noteworthy than the effective weight reduction. Thus water saturation influence could be expressed by a concomitant 
reduction in the thickness of the overburden taken into consideration, which is given by the equation:

$$
\begin{aligned}
& \Delta W=0.3\left(H W-B_{X}\right) \\
& \text { where } \Delta W=\text { equivalent water depth taken into account } \\
& H W=\text { high water level } \\
& \qquad B_{X}=\text { base of the considered number " } \mathrm{x} \text { " formation }
\end{aligned}
$$

In the case of the Brackish Marl and Limestone, one must also take into account the saturation state of the Saint Ouen Limestone: this saturation state induces a more easily propagation of deformation to the surface as the thickness of the "Saint Ouen - Beauchamp" groundwater body increases. Considering that the impermeable upper boundary of this aquifer lies $5 \mathrm{~m}$ above the base of the Beauchamp Sands (value representing the position of the median impervious intercalation), the retained expression in this case becomes:

$$
\begin{gathered}
\Delta \mathrm{W}=0.3\left[\left(\mathrm{HW}_{\text {Lute }}-\mathrm{B}_{\mathrm{BMLL}}\right)+\left(\mathrm{HW}_{\mathrm{SO}}-\left(\mathrm{B}_{\mathrm{bcha}}+5\right)\right]\right. \\
\text { where } \Delta \mathrm{W}=\text { equivalent water depth taken into account } \\
\mathrm{HW}_{\text {Lute }}=\text { high water level of the Lutetian aquifer } \\
\mathrm{B}_{\mathrm{BM \& L}}=\text { base of the Brackish Marl and Limestone } \\
\mathrm{HW}_{\mathrm{SO}}=\text { high water level of the "St Ouen" aquifer } \\
\mathrm{B}_{\mathrm{bcha}}=\text { base of the Beauchamp Sands }
\end{gathered}
$$

When the top of the considered formation is located at less than $80 \mathrm{~m}$ from the topographic surface, the probability of collapse $P_{c}$ will be inversely proportional to the thickness of the overburden (possibly decreased by the thickness of the Beauchamp Sands) minus the equivalent water depth taken into account $(\Delta \mathrm{W})$, as outlined in Figure 15. 


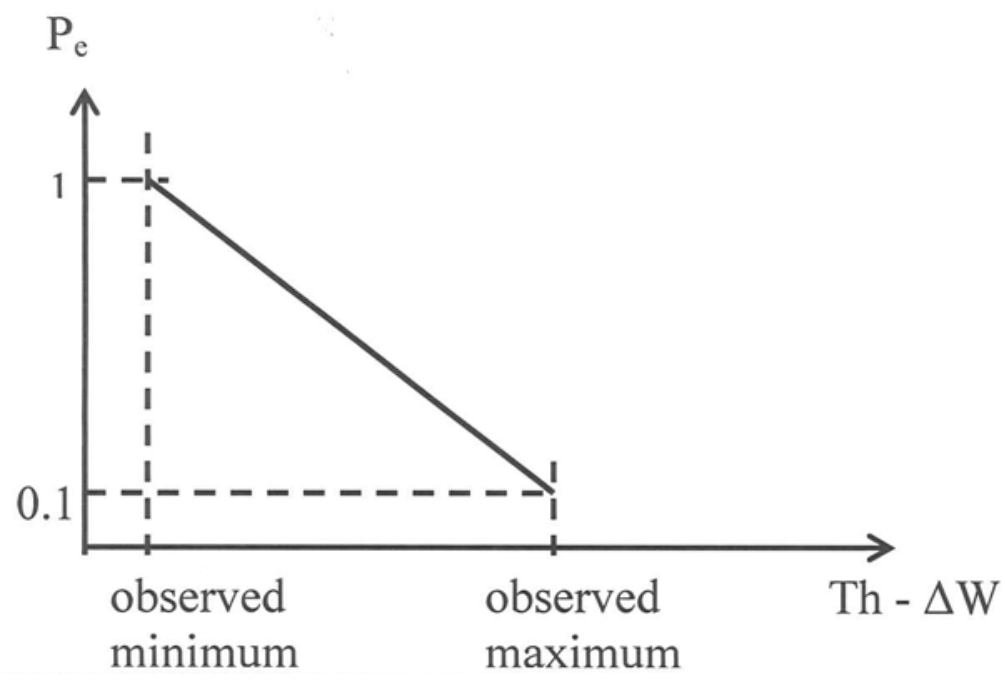

Fig. 15: Method of determining the probability of collapse from the thickness of the overburden and the thickness of the saturated zone

Where the depth of the top of the formation is less than $80 \mathrm{~m}$, the probability of collapse will be a function of the thickness of the overburden corrected by the equivalent water depth according to the formula:

$$
P_{c}=0.1+((1-0.1)(\max -T h) /(\max -\min ))
$$

where $T h=$ local value of the overburden taken into account by subtracting the equivalent water depth

$\max =$ maximum value of Th observed on the map or $80 \mathrm{~m}$

$\min =$ minimum value of Th observed on the map

\subsection{Compiling the subsidence susceptibility map}

The product of the three probabilities makes it possible to compile a subsidence susceptibility map using a pixel size of $20^{*} 20 \mathrm{~m}$ grid step. The susceptibility values vary from 0 to 0.6 . From this it is possible to define four value classes whose definition is based on the analysis of the histogram's distribution of these values and expresses IGC's field experience. For the Brackish Marl and Limestone, the selected thresholds are 0.001 to 0.1 for a low 
susceptibility, 0.1 to 0.2 for a moderate susceptibility, and higher than 0.2 for a strong susceptibility. Below 0.001, the susceptibility is regarded as negligible. Figure 16 shows an extract of the final map.

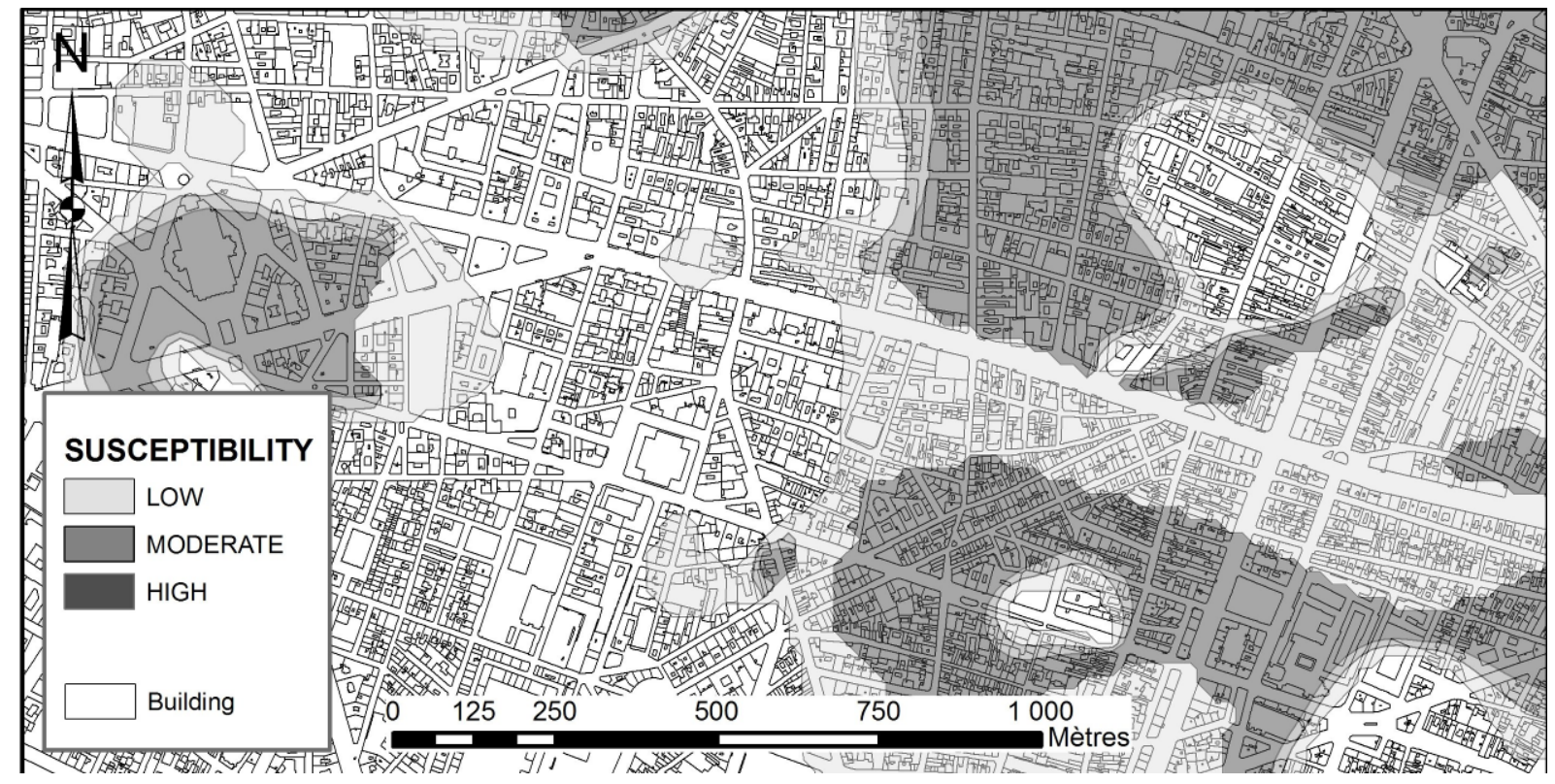

Fig. 16: Extract of the subsidence susceptibility map related to gypsum dissolution in the Brackish Marl and Limestone.

\section{Conclusions and discussion of the results}

The resulting map has been analysed in detail by the IGC specialists. The results clearly correspond to the Parisian authorities' field knowledge as well as to the location of the known problems caused by ground movements, even though clear correlations are not possible due to the uncertainities on damages' real causes. Nevertheless, for certain areas hitherto considered as being outside the sensitive zone (see fig. 17), the study has revealed a risk of localized collapse or subsidence due to the dissolution of pre-Lutetian gypsum; IGC has already planned to investigate these areas. 


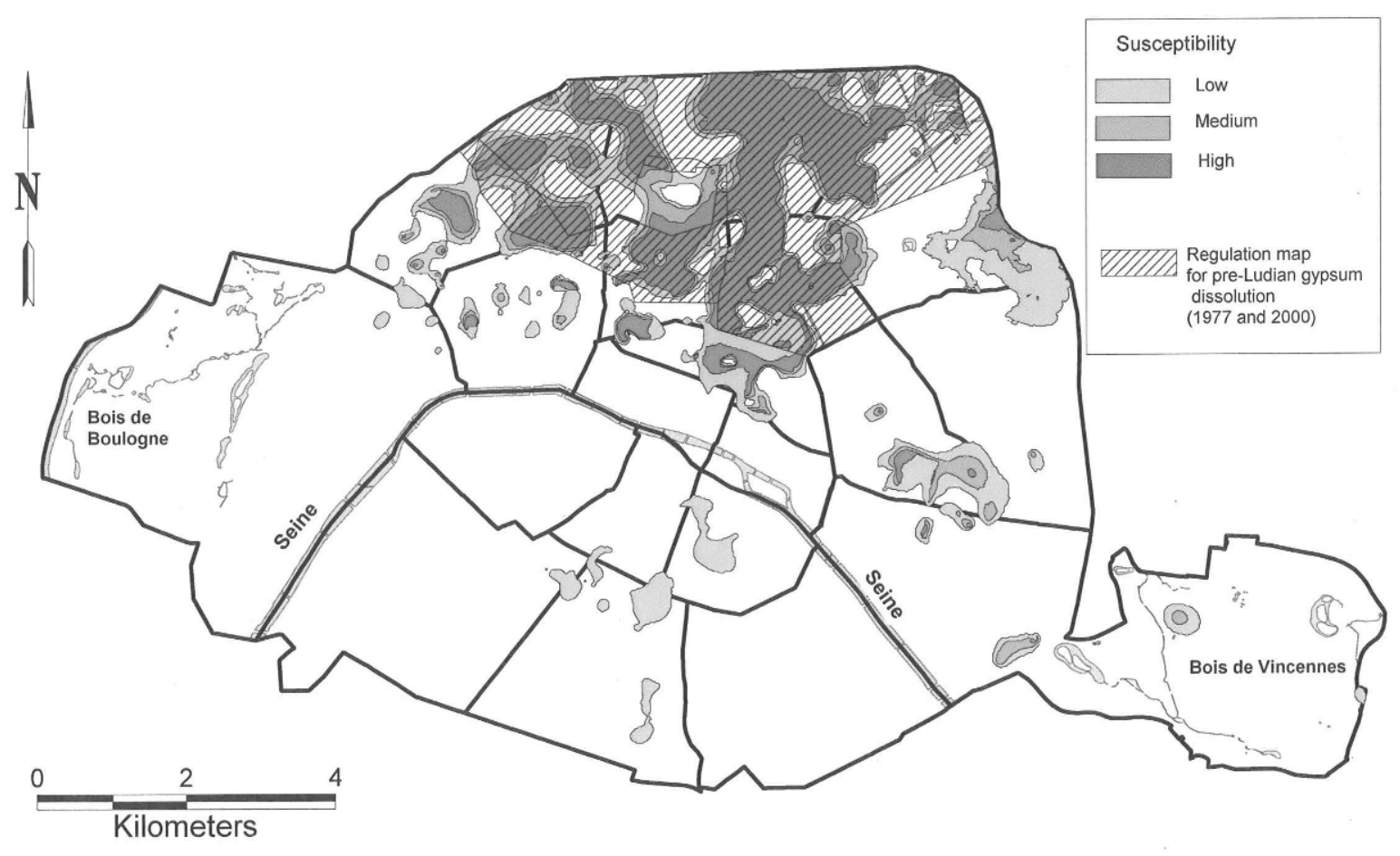

Fig. 17: Comparison between results obtained on Brackish Marl and Limestone formation and the regulation map.

The constructed geological model and the hydrogeological analysis have already been used for studying other phenomena (gypsum dissolution in Ludian formations, sand flow and clay creep).

In such a study, a crucial issue corresponds to the necessity of reaching a level of accuracy, consistent over the whole city, although based on heterogeneous and fragmentary information. This need implies neglecting useful but too local information. Main limitations are related to the urban underground complexity, mainly anthropogenic impacts on urderground water flows and their temporal evolutions.

\section{Acknowledgements}

This work was financially supported by the City of Paris and BRGM. The authors also thank P. Skipwith for translating the initial text and J. Douglas for having carefully checked the text. 


\section{References}

Apel, M., 2006. From 3d geomodelling systems towards 3d geoscience information systems: Data model, query functionality, and data management. Computers \& Geosciences 32 (2), 222-229.

Arnould, M., Le Guillou, P., 1967. Sur les cavites souterraines de dissolution dans les Marnes et Caillasses du lutetien superieur de la region parisienne. Subsurface dissolution cavities in the Marnes et Caillasses of the upper Lutetian in the Paris region. Comptes Rendus Hebdomadaires des Seances de l'Academie des Sciences, Serie D (Sciences Naturelles) 265 (25), 1864-1866.

Arnould, M., 1970. Problems associated with underground cavities in the Paris region. In: Geological and Geographical Problems of Areas of High Population Density. Proceedings of the Symposium, Association of Engineering Geologists, Sacramento, CA , pp. 1-25.

Aug, C., 2004. Modélisation géologique 3D et caractérisation des incertitudes par la méthode des champs de potentiel. Doctoral Thesis, Paris School of Mines (in French)

Auvinet, G., Juarez, M., Medina-Cetina, Z.. 2001. Geostatistical Interpretation of Soil Exploration in Lacustrine Clays. Proceedings of the XIII Conference of the International Society of Soil Mechanics and Foundations Engineering. 2001 Istanbul, Turkey

Bourgine, B., Dominique, S., Marache, A., Thierry, P., 2006. Tools and methods for constructing 3D geological models in the urban environment; the case of Bordeaux. IAEG 2006 Engineering Geology for Tomorrow's Cities, Nottingham, UK, 6-10/09/2006, IAEG Proceedings, paper no. 72.

Bozzano, F., Anderucci, A., Gaeta, M., Salucci, R., 1999. A geological model of the buried Tiber River valley beneath the historical center of Rome. Engineering Geology and the Environment 59(1), 1-21.

Broquet, J.F., 1976. Contribution à la cartographie géotechnique de la ville de Paris - Le XIIlème arrondissement. Doctoral thesis, University of Pierre et Marie Curie. 
Chilès, J.P., Blanchin, R., 1995. Contribution of geostatistics to the control of the geological risk in civil-engineering projects: The example of the Channel Tunnel. In: M. Lemaire, J.L. Favre, \& A. Mébarki (Eds.), Applications of Statistics and Probability - Civil Engineering Reliability and Risk Analysis 2, A.A. Balkema, Rotterdam, Netherlands, 1213-1219.

Chilès, J.P., Delfiner, P., 1999. Geostatistics: modeling spatial incertainty. 1999 Wiley series in Probability and statistics. Wiley

Cooper, A.H., 1995. Subsidence hazards due to the dissolution of Permian gypsum in England: investigation and remediation. In: Beck, B.F. (ed.), Karst geohazards. Proceedings of 5th Multidisciplinary Conference on Sinkholes. Balkema, Rotterdam, 2329.

Cooper, A.H., Saunders, J.M., 2002. Road and bridge construction across gypsum karst in England. Engineering Geology 65 (2-3), 217-223.

De Rienzo, F.; Nardi, G., 2004. Underground urbanism case study; a geological and geotechnical 3D model of Turin (northern Italy) subsoil. International Geological Congress, Abstracts 32 (1), p. 232.

De Rienzo, F., Oreste, P., Pelizza, S., 2008. Subsurface geological-geotechnical modelling to sustain underground civil planning Engineering Geology, 96 (3-4), 187-204.

Dessandier, D., 1995. Etude du milieu poreux et des propriétés de transfert des fluides du tuffeau de Touraine - Application à la durabilité des pierres en œuvre. Document BRGM 245 - Editions du BRGM.

Deveughele, M.; Usseglio Polatera, J. M., 1979. Cartographie des zones exposees aux risques lies aux dissolutions de la fraction gypseuse du Marno-Calcaire de Saint-Ouen dans les $19 \mathrm{eme}$ et $20 \mathrm{eme}$ arrondissements de la ville de Paris. Geologic hazards mapping of zones exposed to risks linked to the dissolution of the gypseous fraction in 
the "Marno-Calcaire de Saint-Ouen" in the 19th and 20th arrondissements of the city of Paris. Bulletin of the International Association of Engineering Geology 19, 121-125.

Diffre, Ph., 1969. Hydrogéologie de Paris et de sa banlieue. Doctoral thesis, Faculty of Science, University of Paris.

Duperret, A., Taibi, S., Mortimore, R.N., Daigneault, M. (2005) Effect of groundwater and sea weathering cycles on the strength of chalk rock from unstable coastal cliffs of NW France, Engineering Geology 78 (2005) 321-343

Easa, S., Chan, Y., 2000. Urban planning and development applications of GIS 2000 Edited by ASCE (American Society of Civil Engineers), 283 pp.

Ellison, R.A., Booth, S.J., Strange, P.J., 1993 Geological mapping in urban areas, the BGS experience in London. Episodes 16(3), 383-388.

Galve, J.P., Bonachea, J., Remondo, J., Gutiérrez, F., Guerrero, J., Lucha, P., Cendrero, A., Gutiérrez, M., Sánchez J.A., 2008. Development and validation of sinkhole susceptibility models in mantled karst settings. A case study from the Ebro valley evaporite karst (NE Spain) Engineering Geology 99, 3-4, 185-197

Ghabezloo, S., Pouya, A., 2006. Numerical modelling of the effect of weathering on the progressive failure of underground limestone mines. In: Van Cotthem, Charlier, Thimus \& Tshibangu (eds.), EUROCK 2006 - Multiphysics Coupling and Long Term Behaviour in Rock Mechanics, Taylor and Francis Group, London ISBN 0415410010 , 233-240.

Gutierrez, F.; Cooper, A. H., 2002. Evaporite dissolution subsidence in the historical city of Calatayud, Spain; damage appraisal and prevention. Natural Hazards 25 (3), 259-288.

Gutierrez-Santolalla, F.; Gutierrez-Elorza, M.; Marin, C.; Maldonado, C.; Younger, P.L., 2005. Subsidence hazard avoidance based on geomorphological mapping in the Ebro River valley mantled evaporite karst terrain (NE Spain). Environmental Geology 48 (3), 370383. 
Jardin, J., 1975. Fondations sur le gypse; experience acquise en Region parisienne.

Foundations on gypsum; experience acquired in the Paris region. Bulletin de Liaison des Laboratoires des Ponts et Chaussees 78, 53-63.

Johnson, K.S., 2005. Subsidence hazards due to evaporite dissolution in the United States. Environmental Geology (Berlin) 48 (3), 395-409.

Lamont Blak J., Younger, P.L., Forth, R.A., Cooper, A.H., Bonniface, J.P., 1999.

Hydrogeological monitoring strategies for investigating subsidence problems potentially attributable to gypsum karstification. In: Beck (Ed.),Hydrogeology and Engineering Geology of Sinkholes and Karst; Balkema Rotterdam, 141-147.

Lu; YR, Zhang, F; Qi, J; Xu, J; Guo, X, 2002. Evaporite karst and resultant geohazards in China. Carbonates and Evaporites 17 (2), 159-165.

Marteau P., 1993. Mémento Roches et Minéraux industriels Gypse et Anhydrite Editions du BRGM

Maurenbrecher, P.M., Herbschleb, J., 1995. Investigating the sub-surface in urban areas for underground spaces with special reference to Amsterdam, In $6^{\text {th }}$ International Conference "Underground Space and Urban Planning", 26-29 September 1995, Paris.

Mégnien, C., 1980 Synthèse géologique du Bassin de Paris Ouvrage collectif sous la direction de C. Mégnien (1980). Mémoires du BRGM N¹01/102/103, 470 pp.

Morfeldt, D., Persson, L., 1997. Research and documentation on the importance of engineering geology in some underground projects in Stockholm. Tunneling and Underground Space Technology 12-4, 473-477

Moynot, G., 1977. Site et structure de la Gare souterraine de Paris-Nord. A.F.T.E.S. Journées d'étude : les travaux souterrains en site urbain, 9-11 Mai, p. 66-71.

Prunier Leparmentier, A.M., 1988. Les problèmes géologiques et géotechniques de la ville de Paris. Doctoral thesis, Ecole Nat. des Mines de Paris. 
Prunier Leparmentier, A.M., 1991. Evolution de la nappe phréatique depuis un siècle dans Paris et niveaux connus en 1990. Rev. Franç. Géotech 56, 67-75.

Soyer, R., 1953. La géologie de Paris. Mem carte géol. Fr ., 610 p., 46 figs., 6 pl., 5 maps.

Soyer, R. 1961. Les dissolutions de gypses anteludiens dans le centre de l'Ile-de-France et leurs dangers pour les constructions. Bulletin de la Societe Geologique de France 3 (5), 432-436.

Thierry, P., Bourgine, B., Vairon, J., Vinet, P., 2000 Methods and tools for constructing a 3D geological model in an urban environment: an example from the west of Greater Lyons. In Decision making in Urban and Civil Engineering - 2nd - Lyon - France - 20-22/11/2000, $1,525-537$

Toulemont, M., 1986. Les gypses lutétiens du bassin de Paris - Sédimentation, karstification et conséquences géotechniques. Doctoral thesis, University of Paris-Sud, Orsay Centre.

Toulemont, M., 1987. Les Risques d'instabilite lies au karst gypseux lutetien de la region parisienne; prevision en cartographie. Risks of instability associated with Lutetian gypseous karst around Paris; prediction mapping. Bulletin de Liaison des Laboratoires des Ponts et Chaussees 150-151, 109-116.

Usseglio-Polatera, J.M., 1980. Contribution à la cartographie géotechnique de la ville de Paris, étude de la butte de Belleville. Doctoral thesis, Pierre et Marie Curie University and Ecole Nat. des Mines de Paris.

Yilmaz, I., 2007. GIS based susceptibility mapping of karst depression in gypsum; a case study from Sivas Basin (Turkey). Engineering Geology 90 (1-2), 89-103. 